\section{Igor Fisković}

Filozofski fakultet Sveučilišta u Zagrebu, Odsjek za povijest umjetnosti

Izvorni znanstveni rad / Original scientific paper UDK / UDC: 728.3(495.7 Orebić)"15/19"

11. 9. 2013.

\title{
Stare kuće pomoraca u Orebićima
}

Ključne riječi: kultura izvangradskog stanovanja, ladanjski prostor, kuće pomoraca, Orebici, urbanizam Key words: the culture of country living, creating new spaces away from the city, houses of seamen, Orebic, urban planning

Sadržaj koji sam namijenio zborniku u čast dragoj prijateljici i cijenjenoj kolegici Nadi Grujić, sigurno bi teže našao mjesta u našoj znanosti bez ukupnih doprinosa te najpredanije i najzaslužnije istraživačice staroga stambenog i ladanjskoga graditeljstva u južnoj Hrvatskoj. Naime, povijesne kuće sagrađene u Orebićima od kapetana i brodovlasnika svojevrsna su simbioza tih dviju spomeničkih vrsta iz dubrovačke renesanse ali i posljednja njihova kreativna redukcija, pa predstavljaju samosvojni fenomen sadržavajući poimanja vrijedna svake pozornosti. Pogotovo s razloga što dosad nisu bile posebno proučavane ni dolično dokumentirane, ovdje ću se prigodno osvrnuti na njihove značajke ne bih li im pospješio uvažavanje i dao polazišta za obuhvatnije istraživanje tematike, koju same te kuće najizravnije nose.

Kuće pomoraca građene od kraja 16. do početka 20. stoljeća u Orebićima ${ }^{1}$ tvore zasebnu spomeničku skupinu o kojoj se malo pisalo. Široko gledajući, one u svojoj suštini nisu različite od glavnine zdanja stambeno-privatne namjene koja su $\mathrm{u}$ istom razdoblju mahom za dobrostojeće građane-pučane nastajala diljem dubrovačkog kraja. Međutim, ove dobivaju na značenju svojom brojnošću u lancu pruženome tik do mora, ${ }^{2}$ a naročito time što iznose na vidjelo sklop osobitosti proizišlih iz specifičnih uvjeta i okolnosti povijesnog života jednog naselja kojemu su združene odredile vizualnu fizionomiju. Usto su s kontinuitetom dugoga trajanja ojačale $\mathrm{u}$ podneblju iskristalizirane modele profane arhitekture izvangradskih prostora, nadasve očuvale razgovijetnima svojstva formalne jednostavnosti kao i neupitnost tipološke ujednačenosti. ${ }^{3}$ Posredstvom toga se vrlo znakovito sa svega nekoliko razvojnih valova otkrivaju lokalno zacrtana ponašanja ljudi u prostoru, ujedno njihov odnos spram oblikovanja povijesne arhitekture privatne svrhe, zapravo lokalne stalnosti jedne od bazičnih grana graditeljstva, što nam je glavna tema raspravljanja.

U osnovi sve te kuće pokazuju civilizacijsku razinu Orebićana koji su ih u etapama gradili isključivo za svoju svakodnevicu, a učinili znamenjem vlastitoga društvenog statusa, kao i odgovorom na ideologizirana poštivanja biranih područnih predaja. No, kako je riječ o pripadnicima srednjega sloja građanstva unaprijed skučenih pretenzija zbog nevisokih im imovinskih dometa, mahom ne posjeduju umjetnički izražajne vrsnoće. ${ }^{4}$ Zato i jesu škrte mogućnosti da im se morfološke karakteristike očitaju u kategorijama stila, ključnog instrumenta naše struke i bitnog kriterija ocjenjivanja baštinskih dobara. Zapravo te kuće, ${ }^{5}$ veličinom odgovarajuće samo pojedinim obiteljskim zajednicama, oslikavaju samosvijest i mentalitet ljudi u prostoru vrlo ograničenog opsega, ${ }^{6}$ te kulturna stanja na krajnjoj granici državice Dubrovnika kao osebujne tvorevine nacionalne nam prošlosti. Premda joj orebićke kuće obogaćuju svekoliku ostavštinu, dvojbeno ih je izravno vezivati u taj korpus jer su se uslijed geografske udaljenosti i više nego slabe prometne povezanosti od njega jako odvojile te postale gotovo vrstom samostalnoga identiteta. Zapravo su stekle vlastitosti koje u neku ruku izmiču iz tješnjih klasifikacija naše struke, pa bi ih možda bilo dovoljno samo fotografskim prikazom upisati u javnu memoriju. Ali kako one u tome polju dugo već žive razvidno prkoseći i današnjem, spram naslijeđu iz 


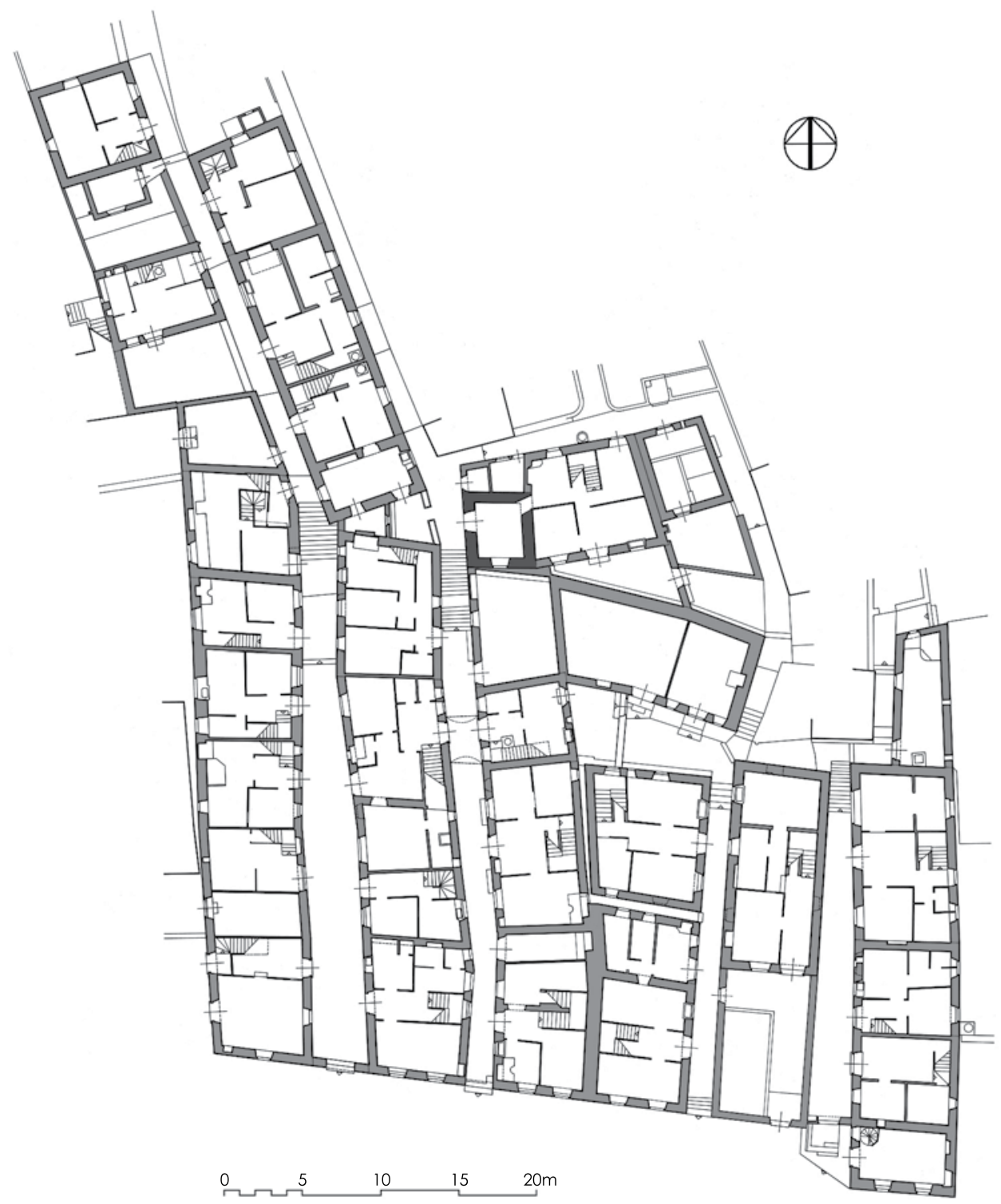

1. Tlocrt prve stambene jezgre Orebića (arhitektonski snimak: Institut za povijest umjetnosti, D. Stepinac, 1966.) / Plan of the first residential nucleus in Orebici (architectural recording: Institute of Art History, D. Stepinac, 1966)

starine »nejunačkom vremenu«, korisnim se čini o njima iznijeti spoznaje koje su sastavni dio humanističke discipline povijesti umjetnosti.

Svrhom toga valja zaći u razdoblja malo starija od nastajanja tridesetak građevnih djela na kojima se osobito očituju postignuća jedne izrazito pomorske, $u$ svojoj biti polururalne sredine prodičene tek s ponekom oznakom urbaniteta, što je također osobiti fenomen. Naselje Orebića, naime, nije podleglo standardizacijama starog urbanizma primorske Hrvatske sa zbijeno okupljenom množinom zgrada uobičajeno različitih sadržaja, ${ }^{8}$ nego se pružilo uz rub mora umah iskazavši glavne privredne orijentacije svojih žitelja. Smjestilo se na zapadnome dijelu poluotoka Pelješca, s južne mu otvorene strane uz prometni kanal, ${ }^{9}$ na slabo plodnome terenu koji nije omogućio izdašno vinogradarstvo ili maslinarstvo, što bijahu temeljni izvori i pretežni oslonci opstanku podanika Dubrovačke Republike izvan njezina urbanog središta. Udaljenost od toga vjekovnoga upravnog centra, kao i položaj pri morskoj granici s trajno mu neprijateljskom mletačkom državom, ${ }^{10}$ sigurno su im pospješili okretanje pomorstvu, potom i brodarstvu kad je istočni Jadran ušao u sastav velikih, europski svemoćnih političkih tvorevina. ${ }^{11}$ Sređenosti tih novih vlasti i postupno pospješivanje općeg puta $\mathrm{k}$ boljitku uvećali su razmjere privatno-stambene izgradnje koja je izborom arhitekturalne tipologije iznad svega odražavala nemalu posebnost orebićke sredine. Međutim, u pogledu morfologije nije ostvaren odlučni progres u odnosu na ono s čime se $\mathrm{u}$ istome kraju do druge polovine 16. stoljeća bijaše iskazao posve zapadnjački obilježen procvat ponosne južnohrvatske državice.

U tom smislu relevantno je oblikovanje prvog nukleusa povijesnog i današnjeg Orebića, inače problemski sagleda- 


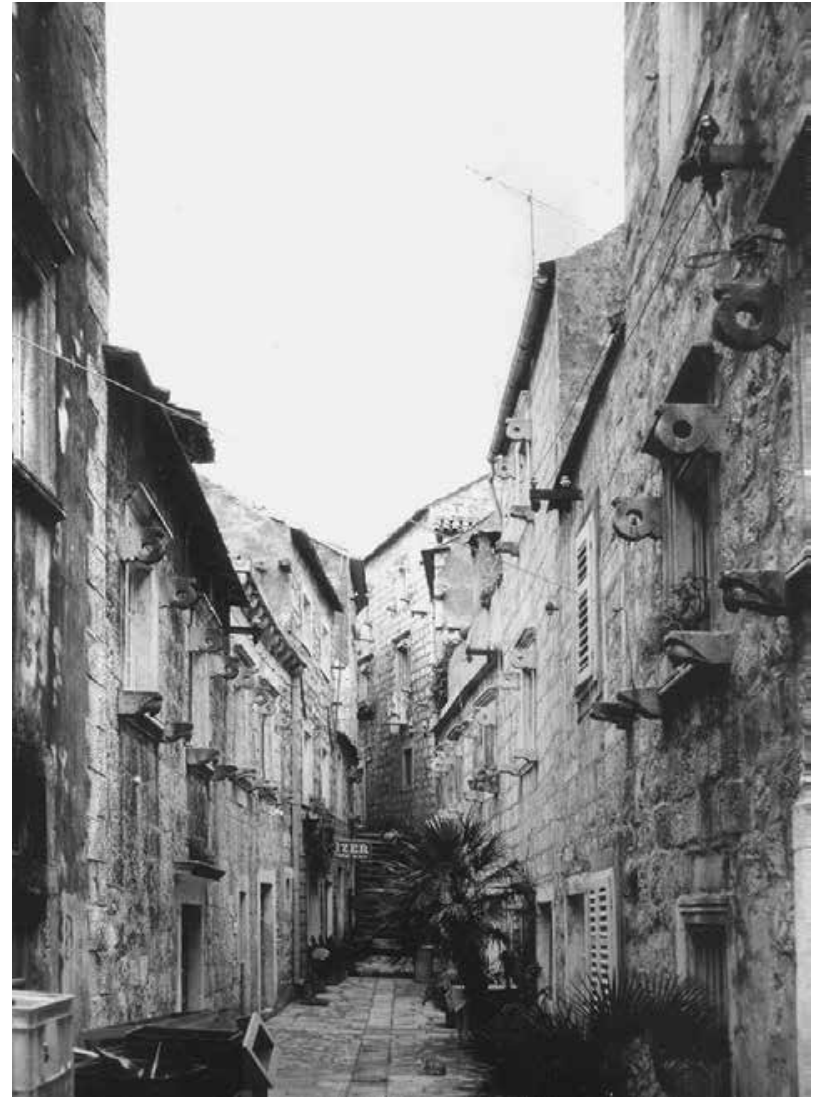

2. Jedna od ulica u staroj jezgri / A street in the historic core

noga dovoljno da se shvati koliko je drugačiji od svega čime se profiliralo novodobno naselje. No, u oblikovanju stambenih kuća, što nam je u žarištu zanimanja, razabiru se ipak neke osnove od važnosti za spoznavanje evolucije odigrane na licu mjesta. Naime, prva se ovdašnja naseobina podudara $s$ iskustvom zrelog srednjovjekovlja sročenog tipizacijom planiranih naselja, ${ }^{12}$ ponajprije dijela grada Dubrovnika pa potom i Stona na drugome kraju dugačkog i uskog poluotoka. Po sličnim se urbanističkim matricama s izvjesnim kašnjenjem formirala naseobina koja nije dostigla dimenzije ni status grada, ${ }^{13}$ ali je zacrtala smjer povezivanja s biranim stečevinama regije i otvorila procese koji će se slojevito u više vidova nastaviti. Premda se još ništa pouzdanoga ne zna o njezinu osnutku, svi su izgledi da je zaživjela od 15. stoljeća, programski utemeljena od dubrovačke vlasti, te je strogi njezin politički režim prenesen u prostorno-arhitektonski uravnoteženo tkivo, unutar kojega je sazidano za današnja viđenja dosta kvalitetnih zgrada pučkog stanovanja.

Zato se uime potvrda mikroregionalnih identiteta najprvo osvrćemo na očigledne srodnosti prostornih struktura najstarije životne jezgre Orebića s najmlađom četvrti Dubrovnika i sekundarnim dijelom Stona. ${ }^{14}$ Zajedničko im je određenje pravilni sistem ravnih usporednih ulica uz koje se protežu blokovi međusobno povezanih katnica na kata- starskim česticama malih mjerila. Prvotna ih aglomeracija ima pet ponešto asimetričnih, ${ }^{15}$ jer joj glavni dugački blok tvori dvored kuća kojima lica definiraju ulice, a otraga se izravno naslanjaju jedna na drugu, ${ }^{16}$ dok ostale ostvaruje tek po jedan niz. Osnovna im je zaklopljenost s triju strana pomoću pravolinijski spojenih vanjskih zidova kuća jamčila obranu od neprijatelja, ${ }^{17}$ a usmjerenje ulica od juga prema sjeveru omogućilo je žiteljima permanentnu komunikaciju s morem i poljem kao ključnim uporištima života. Takav racionalni sistem jasno upućuje na strategiju dubrovačke države koja je čuvala vlastiti teritorij na izloženome mjestu, a slijedno potrebama svojega gospodarstva pružila sigurni smještaj kmetovima zaposlenima na zemljoposjedima vlastele. ${ }^{18} \mathrm{U}$ svakom slučaju razlike prema znamenitijim uzorima objašnjive su dobnom i prostornom udaljenošću od njih, kao i obujmom poduzimanja glavnog pokretača te izgradnje. Ali sudeći po skladu pročelja više kamenih kuća i dorađenoj renesansnoj frazeologiji prozorskih okvira, ${ }^{19}$ valja računati na početak ulaganja sposobnijih ovdašnjih pojedinaca u stanogradnju kad još nisu raspolagali s ionako oskudnim zemljišnim imanjima. Upravo uz odmicanje od poljoprivrede, oni su u čak rizičnijem ali obećavajućem pomorstvu nalazili podlogu izražavanju kako opće ljudske težnje za napretkom, tako vlastite socijalne svijesti već pomalo obojene staleškim prestižem. U tom se smislu do danas postojeća prva stambena jezgra Orebića potvrdila mjestom ranog upućivanja oblika arhitekture sazrijevajućih pri daljnjem građenju kuća Orebićana, otada uzdizanih na položaj zapovjednika i velikih jedrenjaka. ${ }^{20}$

Jedva stoljeće poslije u istim je uvjetima narasla istočnije uz more druga zbijena naseobina Fiskovića selo, ${ }^{21}$ obrisom nepravilnija a razvedenija u tlocrtnom rasteru. No, ni ova nije dostigla potpunost urbanoga organizma, nego je sa samo stambenim zgradama složen sustav od jednog okomito prema moru usmjerenoga niza koji tvori jedinu ravnu ulicu. Nemajući dužinu onih iz prve jezgre, ona se aritmički pretače u poprečne prostore definirane kraćim redanjem katnica okrenutih jugu i popraćenih dvorištima u vidu uskih "prikuća» - privatnih mjesta zadržavanja suprotstavljenih aksijalnoj, kolektivnoj komunikaciji ulice kojoj slabi značenje. ${ }^{22} \mathrm{Na}$ prikućima se naime u relativnoj sigurnosti izvana zatvorene aglomeracije intimnije koncentrirao statički život imućnijih domaćih ljudi. Prekidan je odlascima muškaraca na plovidbe, koje se tu i dočekivalo po povratku, pa će se taj specifični predložak koristiti pri artikuliranju čitavih Orebića kad zamru upadi gusara i promijeni se područni agrar. Međutim, objavile su se neke novine pri oblikovanju gotovo spontano raspoređenih većih katnica, koje oko sebe razmještaju gospodarske zgrade usitnjavajući strukture cjeline, a uzorno oplemenjuju svoje vanjštine. Uz umnažanje uniformno po izričaju onoga doba klesanih okvira njihovih prozora s konzolama i menzolama, naime, na nekim pročeljima su dekorativnije oblikovani portali i istaknuti kameni 


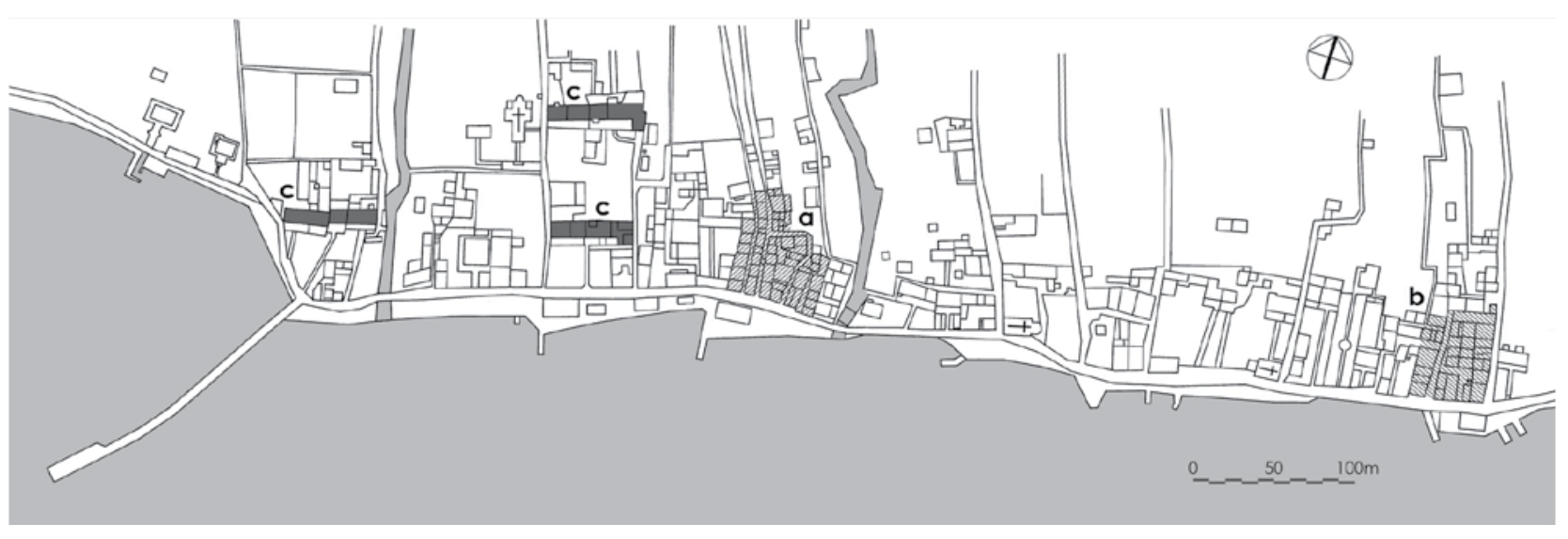

3. Prostorna situacija naselja početkom 20. stoljeća; a - najstarija jezgra, b - Fiskovića selo, c - stambeni nizovi, zaselci (arhitektonski snimak: Institut za povijest umjetnosti, za tisak obradili I.Tenšek i D. Zuljan) / Position of the settlement in the early 20th century: $a-$ the oldest nucleus, $b$ - Fiskovića village, c -rows of houses, hamlets (architectural recording: Institute of Art History, graphics by I. Tenšek and D. Zuljan)

balkoni s ogradama od stupića. Središnje pak postavljena vitka trokatnica na vrhu ima lođu, i to ugledom na gradska rješenja ne samo s ulogom obrambene izvidnice. ${ }^{23}$ Ostala je većina jednokatnih kuća gabaritno ojačana s nejednakim volumenima i dosljedno razdvojenim krovovima, a iznutra simetrično ustrojena s više prostorija. ${ }^{24}$ Usto se može zaključiti kako je socijalno raslojavanje stalnih žitelja urodilo čednim srokom modernizacije svjetovnoga graditeljstva pomoću prostorno-shematskih motiva, ali i stilskih elemenata koji će $\mathrm{u}$ istom okruženju postati paradigmatskim formulama.

Daljnji su korak izgradnje Orebića sačinila podalje od mora dva međusobno rastavljena niza od po pet-šest malih jednokatnica - Štukovo selo i Kovačevićevo selo. ${ }^{25}$ Nazivi su im izlučeni iz prezimena starih rodova jer su služili zadružnom stanovanju, što odaje jedinstveno "prikuće« pruženo smjerom istok - zapad uz jedini red kuća jedva viših od njegove širine. Čitava formacija nalikuje ulici, ali to ipak nije dočim u obje te grupe kuće imaju ograđene prednje vrtove i stražnja dvorišta, a radi sigurnosti čitav se sklop zatvarao vratima na oba kraja. ${ }^{26}$ Dakle, za ustroj uvjetno mlađih nukleusa odlučna su bila okućivanja domaćinstava podalje od mora, a kako su nekima uz pročelja prislonjene vanjske stube uzlaza na kat, ${ }^{27}$ to je očitija privatna narav tih svojevrsnih zaselaka. Po sebi skromni, oni nisu jako promaknuli mjesna građevna iskustva, dočim razmjerno uske stambene jedinice pravokutnih tlocrta ne omogućavaju više od para prostorija u prizemlju i na katu: dolje konobu i kuhinju, a gore male sobe, što im odaje ruralne korijene. I dok štedljivo raspolaganje prostorom gradnji upozorava na sporo otklanjanje dubrovačkih vlastelinstava, dotle učestalost klišeizirane kamene plastike na embrionalno tipiziranim kućama dokazuje uklapanja sve poduzetnijih Orebićana u proizvodno-nabavni ciklus stilske građe, koji se otprije razvio između susjedne im Korčule i puno daljeg Dubrovnika. ${ }^{28}$ Ipak, budući da se ni u jednom od tih središta stanovanja ne nalazi striktne i potpune predloške opreme i uresa kasnije većinskim ovdašnjim kućama, uporaba tek nekih motiva iz oblikovanja stambenoga graditeljstva dvaju najjačih gradova u južnoj regiji upućuje na ustaljivanje lokalnih modusa i pravaca izražavanja domaćih ljudi.

Bitno je, međutim, da četiri dosta suglasno smišljene arhitektonske cjeline ne govore toliko o posezanjima stila koliko o prilikama života u okruženju, koje nije steklo snage za gradograđevne zahvate. Kao i svi ostali Pelješčani, naime, Orebićani su prebrodili stoljeća u sastavu Dubrovačke Republike pod stegom staroga kmetstva od koje se oslobađahu tek sa sve uspješnijim okretanjem moru. Vješti su mornari postajali traženi časnici i zapovjednici, isprva samo sudionici u brodarskoj trgovini, a potom i suvlasnici jedrenjaka duge plovidbe što im osiguravaše sve veću dobit. ${ }^{29} \mathrm{~S}$ njome su otkupljivali zavičajne zemlje lišavajući se teških nameta, a dostizali i puna prava građanstva jer su podanicima Republike državni zakoni jamčili ine povlastice po izlasku iz njezinih granica. ${ }^{30}$ Razumljivo je taj put afirmacije vodio emancipaciji, te doveo do iskazivanja dostignutih sloboda posredstvom građenja domova koji se očekivano povedoše za primjerima na dohvatu im ruke postojećih svega nekoliko ljetnikovaca dubrovačke vlastele. Dočim im svrha bijaše u nadzoru imanja i skupljanju ljetina, ${ }^{31}$ a ne ladanju u punome smislu riječi, bili su znatno skromniji od brojnih uokolo glavnoga grada. Međutim, upravo su ovi bez osebujnosti na Pelješcu nedostižnih tema i motiva, ${ }^{32}$ poslužili kao polazište elitnoga tipa kapetanskih kuća na kojima se suvislo primjenjivao niz prijašnjih stečevina lokalne stanogradnje, ali su se promijenile dimenzije pa s njima razumljivo vanjske i unutrašnje strukture.

Ukratko govoreći, kad su Orebićani postali stvarni posjednici zavičajne im krajine, prionuli su građenjima stalnih svojih bivališta samo načelno nalik nekoć povremenim boravištima dotadašnjih gospodara zemlje i ljudi. ${ }^{33}$ Idealni su uzorak primjerili vlastitim mogućnostima, svojoj volji i shvaćanjima, te su ga osiromašili i izblijedili, ali se zamisao 


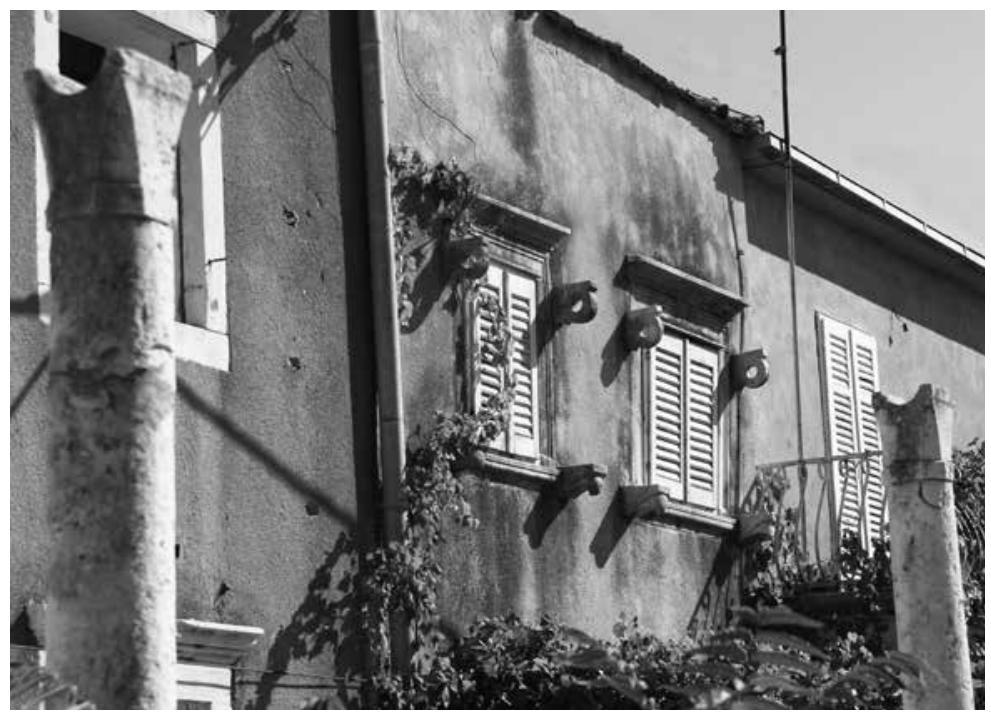

4. Dio pročelja renesansne kuće u Kosovića-Štuk selu / Segment of a Renaissance house in the Kosović-Štuk village

ipak prepoznaje. Po njoj su se naime tijekom 17. stoljeća izvan prve četiri zatvorene stambene aglomeracije počele graditi pojedinačno duž obale razmještene nove i veće kuće. Vrhunac se dostiglo s blagostanjem u 18. i 19. stoljeću, kad je naročito ojačalo mjesno pomorstvo i uznapredovalo brodarstvo, ${ }^{34}$ čime su se odvojili od podložnosti Dubrovniku pa to iskazali u stvaralaštvu kojem su se usredotočili u zavičaju. Zapravo je gradnja tih kuća sažela ako ne jedini, a ono sigurno vrlo pouzdani način opredmećivanja kreativnih poriva i ambicija pučanstva živućeg izvan gradova. Pritom je poredak međusobno razdvojenih i vrtovima opkoljenih zgrada u lancu na rubu mora, bez ikako naglašenoga centra predanih konfiguraciji terena, suodredio čitku tipologiju arhitekture s kojom se prigodice bavimo. Primarna joj je kakvoća u korištenju danosti okoliša s kojima su se posve stopila ljudska djelovanja postižući za ovdašnje prilike odlične rezultate u pitanjima sređivanja okvira življenja sve bogatije društvene zajednice, ${ }^{35}$ ali ne i u pogledu stilske artikulacije kuća, koju je njihova postupna tipizacija iznimno jako upokorila. Dapače su pri njihovu oblikovanju neke običajne formule u rješavanju pojedinosti obilježile jednadžbe cjelina unekoliko čak protivne tekućim stilskim modama.

Ritmički je pak razmještaj jedinica te arhitekture odredila katastarska podjela čitave zaravni podno brda Sv. Ilije, sigurno zacrtana pri potpadanju Pelješca u ruke Dubrovčana, a možda trajuća još iz rimske antike. ${ }^{36}$ Kako je prelazila u svojinu domaćih ljudi, to je postajala još čvršća kad je postavila obalnu frontu građenja njihovih domova. U svakom slučaju, raspored novih kuća ovisio je o zemljoposjedu i nije se podvrgavao nikakvoj hijerarhiji, to više što pomorce nisu zaokupljala djelovanja u oblikovanju javnoga prostora. Zapravo se oni nisu nimalo trudili oko njegove regulacije, o

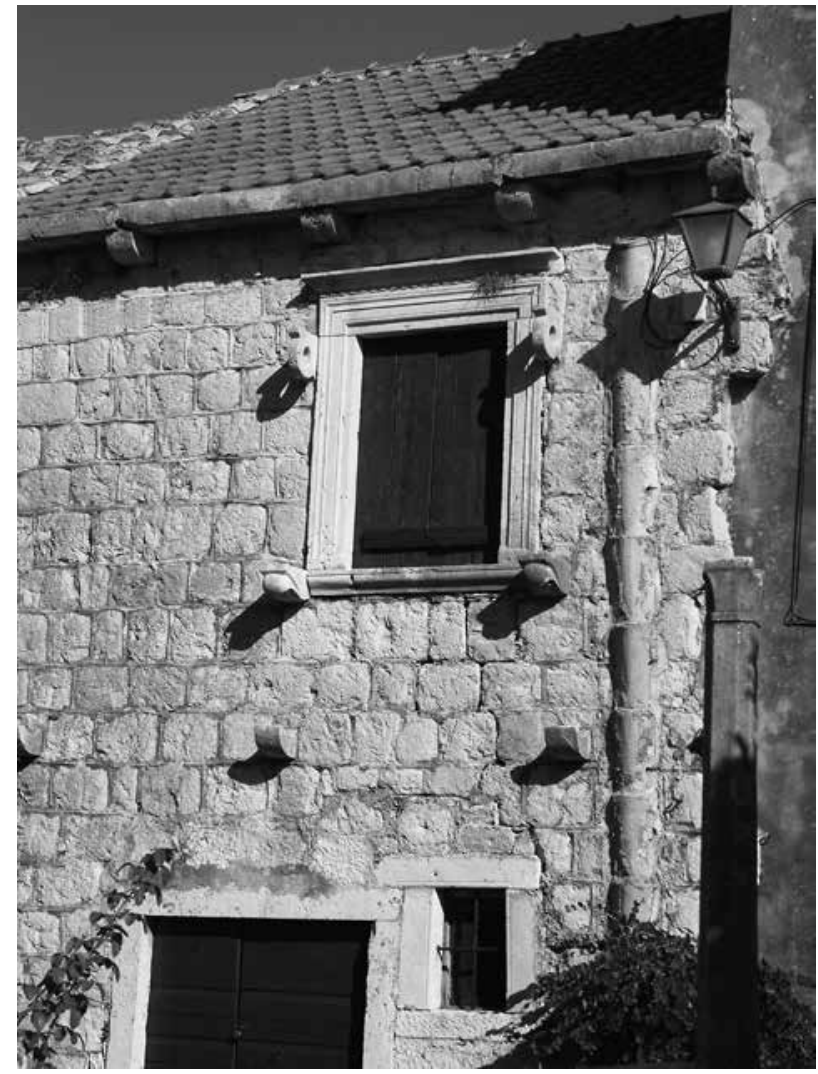

5. Pročelje kuće u selu Kovačević / Front of a house in the Kovačević village

čemu nije skrbila ni dubrovačka vlast, nego su prema zatečenoj geometriji terena svoje novogradnje naredali uz jedini puteljak koji je pratio prirodnu liniju obale ne priječeći izlaz na more svake pojedine. ${ }^{37}$ Usto su rastuće naselje sazdali bez unaprijed cjelovito stvorene predodžbe, a jednu po jednu kuću gradili s težnjom za stvaranjem ogledala u kojem gledaju sami sebe, također ne krijući kako tu sliku nastoje pokazati sumještanima. Parametri vrijednosti uglavnom su vezani uz veličine monolitnih zdanja, ali se ne može poreći i u to ugrađeni spektar pojedinosti kojima se baratalo za potvrdu samovolje njihovih naručitelja i korisnika. Uz takve pretpostavke zasnovane na materijalnim mogućnostima ali i svjetonazoru i moralu kućevlasnika-brodara sklonih međusobnom takmičenju na više planova, obzor ambijentalnosti stjecao je sve veću važnost,$^{38}$ protkanu posvajanjem i održavanjem otprije u užoj regiji provjerenih činitelja svjetovnih gradnji. U svemu se zapravo očitovao odnos naraštaja prema okolini kao jedna od latentnih oznaka svekolikoga čovječjeg iskustva pri izražavanju uljuđenog postojanja u rodnome im mikrosvijetu.

Budući da su Orebići do u pozno novovjekovlje ojačali svoju ulogu matičnog središta reljefno najotvorenije zone Pelješca, rast im je dinamiziran izražajnije nego ostalim naseljima na poluotoku. Zajednički im počeci mahom da- 


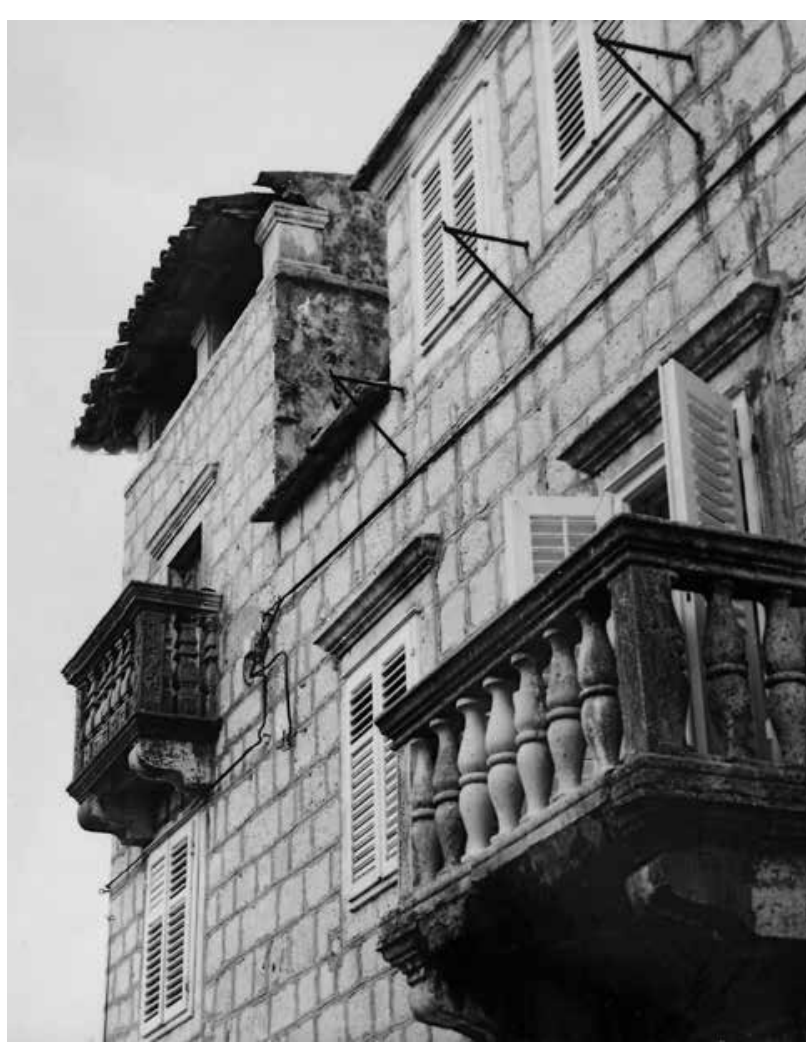

6. Pročelje kuće Kerša s balkonima i lođom u Fiskovića selu / Front of the Kerša house with balconies and loggia in Fiskovića village

tiraju iz srednjeg vijeka, a bez obzira na to što nema točnih zapisa o osnutku svakoga pojedinog, iskorak je stambene, općenito nezahtjevne arhitekture ovdje učinjen primjernim. Njezin je dodir sa stremljenjima baroknoga razdoblja jedva dokaziv u količini i kakvoći motiva klesarske izrade elemenata kojima su raščlanjene građevne jedinice sazdane u ljudskom oku ugodnim proporcijama. Onoliko pak koliko one pripadaju živome tkivu višestoljetnoga malog naselja, toliko je i njima kao i istovrsnim rješenjima iz navedenih starijih grupa, otežano odrediti potanju kronologiju. Međutim, nema dvojbe da su uz preuzimanja viđenih oblika ili ponavljanja modusa obrade njihovih pojedinosti, s vremenom povećavane dimenzije građevina, ${ }^{39}$ jer se poglavito time kovao prestiž među ljudima jednolikih profesija živućih u stanovitoj izolaciji. Zato se za tumačenje tipologije domova sve samopouzdanijih kapetana i brodovlasnika držimo konteksta lokalne povijesti, jer je ona neposredni izvor i presudni okvir stvaralačkih posezanja i uspjeha društvenog sloja odgovornoga za konačni izgled Orebića do modernoga doba. ${ }^{40} \mathrm{~A}$ taj se lik nije sveo samo na dugački uzmorski lanac nego je mjestimice zaokupio i terene iza njega, postupno po dubini prodirući uz češljasti poredak ulica koje se ravno prosljeđuju u putove pravilnih razgraničenja obradive zemlje na zaravni sve do brda. Rezidencijalne su zgrade na taj način porazmještene rastresito na prostoru većem nego

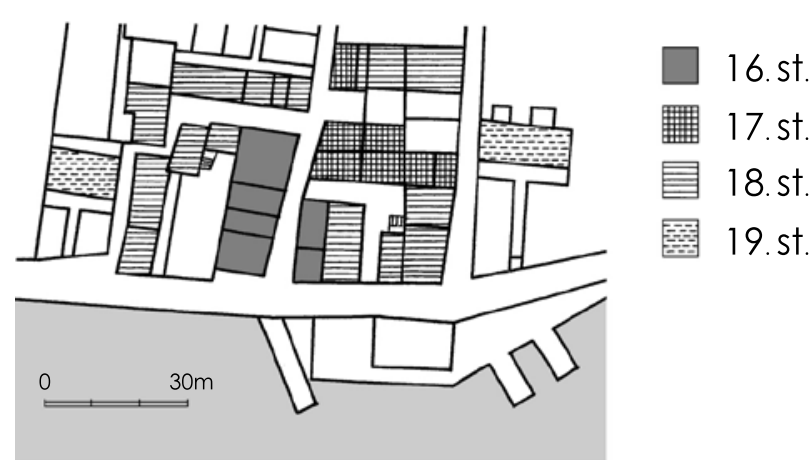

7. Shematski nacrt Fiskovića sela 16.-19. stoljeće (arhitektonski snimak: Institut za povijest umjetnosti, za tisak obradio D. Zuljan) / Shematic plan of Fiskovića village 16th to 19th century (architectural recording: Institute of Art History, graphics by D. Zuljan)

ga obuhvaća prvi, frontalni njihov red i s nekoliko uskih poprečnih prolaza trasiraju daljnje podizanje kuća i rast naselja posebice u srednjem dijelu, ${ }^{41}$ gdje je ostala nepromijenjena najstarija stambena jezgra. U sebi posve stisnuta i zaklopljena, naravno, ona nije podala nijedno svoje obilježje okolnoj, u obalnoj zoni rastresitoj izgradnji nadasve zato što se uz opsežne ekonomsko-političke promjene preobrazio cjelokupni sistem lokalnog življenja. Brojnije su pak nove kuće utjelovile trijeznu samoživost sredine i koliko ona bijaše postojana, toliko se odrazila u njihovoj građevnoj tipologiji.

Temeljni je tip dotičnih kuća smišljen i ostvaren u jedinstvenome kubičnom a samostojećem volumenu, obligatno s pročeljem okrenutim prema Pelješkom kanalu kao vezom sa svijetom. Jednokatnica je približno koliko i dvokatnica, dok su trokatnice iznimne, ${ }^{42}$ a sve im se dimenzije međusobno usuglašavaju u čitkim geometrijama te im je lako raspoznati module. Harmonije su postizane odnosom između strogo prizmatične mase čitave građevine, te rasporeda i veličina zidnih otvora: prizemnih vrata i više po katovima poredanih prozora, na istome objektu ujednačenih mjera i redovito uspravljenih pravokutnih obrisa. Držeći se pak inače uvriježenih »zlatnih « simetrija na svim fasadama, ${ }^{43}$ svejedno je kako se one postižu - s punim zidom ili svjetlosnim otvorom na sredini, odnosno parnim ili neparnim brojem mahom istih otvora, dok im se dispozicije po etažama obvezatno podudaraju. U malo je slučajeva primarnu geometriju dopunio balkon na prvome ili drugome katu, neujednačeno velik i različito oblikovan s ukrasnim ciljem. ${ }^{44}$ Suštinski su jednostavne intencije urodile smirenošću kompozicija, koje gdjekad snaži vodoravna razdjelnica katova u vidu plitkog vijenca po dužini fasade, a oplemenjuje linearna obrada kamenih okvira otvora ulaza i prozora, klesanih više slijedom običaja nego duha doba kad je pojedina kuća sagrađena. Naravno, ovisno o moći ulaganja vlasnika u te skuplje, za vanjsku dojmljivost najučinkovitije elemente, glatko rađeni okviri pretežu u novijem dobu inače sklonome pojednostavljenju formi, a nagrizenome rasipanjem osnovne grane ovdašnje 


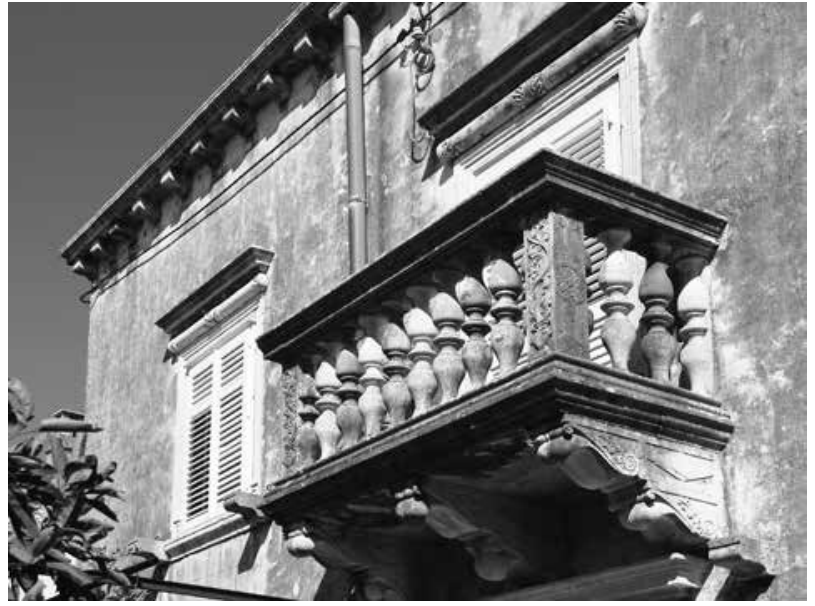

8. Barokni balkon na pročelju kuće Flori-Cvitković / Baroque balcony on the Flori-Cvitković house front

ekonomije. ${ }^{45}$ No, brojni se okviri iz starijega sloja priklanjaju vrlo plitkim renesansnim profilacijama ili streme baroknoj reljefnosti s naglaskom na gornjoj gredi koju udvostručuje uski zaobljeni »jastuk« a zaključuje stupnjevano istureni arhitrav. Tako su pomoću nenametljivih elemenata oživljene plošne površine u pravilu ožbukanih vanjskih zidova koji su još i različito bojeni, ${ }^{46}$ pa je rijetko viđena polikromija mnogim tim kućama podala pompoznost. Kubična pak zatvorenost masivnih i samostalnih volumena učinila ih je monumentalnijima nego zbiljno jesu, a krajnje im se ne može zanijekati doza socijalno zadane razmetljivosti. Susljednim se njihovim pozicioniranjem u prostoru izazvalo vrlo upečatljivu, za mediteransko podneblje pomalo stranu dramatiku koju živom drže atmosferske promjene. ${ }^{47}$ Dakle se bez pogovora zbrajahu formalne značajke koje nisu očitije $\mathrm{i}$ intenzivnije gotovo u nijednome drugom naselju jadranskih obala, te Orebiće čine odista jedinstvenima.

Osobitosti tih kuća su i u artikulaciji krovova, uobičajeno uzdužno šatorastih, no s bočnim stranama ukošenima od polovice visine i trokutasto spojenih s hrbatom konstrukcije. Čisto piramidalnih krovova uopće nema, dok raščlambu navedenih pojačavaju različito istaknuti svjetlarnici, koji tavane uvode u znatniju funkciju ali nisu baš time prouzročeni. Uzdižući se nad zidom pročelja i potpuno im pripadajući, redovito su perforirani parom prozora te odlučno harmoniziraju lica tipiziranih kuća. ${ }^{48} \mathrm{U}$ tom su smislu proporcionalno odmjereni i inim manjim krovištima, te trostranim skošenjima i njima uvećavaju slikovitost, pogotovo kad završavaju zabatima ili imaju bočne volute. ${ }^{49}$ Svemu su pak formalno složni gusti nizovi kamenih zubaca na završnim vijencima, zapravo nosača profiliranih kanala kroz koje otječe kišnica s krovova do cisterni unutar temelja samih zgrada. Iako su sve to na uzmorju prilično uvriježena rješenja, izrasla iz stoljetnih navada koje namirivahu i klimatske uvjete podneblja i estetske prohtjeve naraštaja, u Orebićima imaju osobita značenja zbog dinamičnog smjenjivanja u razigranom poretku moru i suncu okrenutih otmjenih kuća. ${ }^{50}$ Rezultanta ovisi više o zadovoljavanju praktičnih i ideoloških potreba nego o mijenama ukusa kao sastavnici privatnih projekata i realizacija izvan grada živućih ambicioznih ljudi rentabilnih pomorsko-brodarskih struka, koje su ih izoštrile u poimanjima discipline i odgovornosti. ${ }^{51} \mathrm{Na}$ tome se zasniva i zbilja da se oko jednostavnih zadataka osiguranja kvalitetnog suživota u zajednici, pomoću nevelikih sredstava postigao prilično značajan učinak. Uz nazočnost prosječno vještih građevinskih majstora - bolje reći zidara nego graditelja - sposobnih rješavanju tek osnovnih zanatskih, nipošto složenih ili naročito zahtjevnih zadataka, unaprijed bijahu suzbijena ikakva individualna pregnuća a prikraćena i sva likovno intrigantna. ${ }^{52}$ Postignuta je ozbiljnost vlasnicima ulijevala osjećaj pune sigurnosti, kakav je inače moreplovcima izloženima mnogovrsnim nedaćama uvijek nedostajao, a u sklopu rješavanja teme stanovanja postignuta je komotnost boravku svih članova obitelji kao i bazično održanje vrijednog imetka, te stvarno ili simbolično očuvanje trajnosti pojedinačnog posjeda.

Te su kuće sumi repeticije svojih oblika i sadržaja pridodale vrlo ujednačeno osmišljene unutrašnjosti s uglavnom simetričnim rasporedom nužnih prostorija, ${ }^{53}$ što također potpada fenomenu tijesne tipizacije arhitekture koju ogledamo. Njihov se položaj a donekle i razmjeri mogu dokučiti već po poretku vanjskih otvora, ali im potanja svrha u okvirima obiteljskog života, naravno, ovisi o inim objektivnim okolnostima. No, tradicionalni se ipak sistem slijedom količine primjera može izlučiti, te ostaje ključno što kao i izgled eksterijera slijedi običaje starije od barokne epohe. Prizemno su obično oko središnje saloče, kao ulaznog predsoblja po dubini kuće, ${ }^{54}$ četiri manje prostorije: u prednjem planu gostinjska soba zvana veliki tinel, te blagovaonica mali tinel, u stražnjem najmanja spavaonica za poslugu, a sučelice poveća kuhinja sa zasebnim izlazom..$^{55}$ Jednokrako stubište se najčešće uspinje uz sjeverni zid, a prostor pod njime služio je za mračno spremište i kad se uvelo dvostruko lomljene stube. ${ }^{56} \mathrm{Na}$ prvome katu je četiri do pet spavaćih soba oko veće dvorane - sale, namijenjene boravku tijekom hladnijih mjeseci, ${ }^{57}$ a u gornjem katu mahom isti je raspored predviđao smještaj mlađih ukućana ili eventualnih gostiju. Takvo je ustrojavanje prostorija bezuvjetno osiguravalo komotno stanovanje potrebno od plovidbi zamorenim pomorcima nakon povratka u zavičaj i okrilje obitelji pa se od njega nije odustajalo. Niska potkrovlja su se bez normiranja više-manje koristila kao ostave ili za sušenje voća poput nad prizemnim i posvođenim dogradnjama ponegdje pruženim terasama omeđenim zidanim klupama. ${ }^{58}$ Dakle, nužnosti se stapahu s trijeznim osjećajem reda, ovdje pojačanog usporednošću s redom što je morao vladati na jedrenjacima, neizostavnima za razumijevanje svijesti pomoraca. 


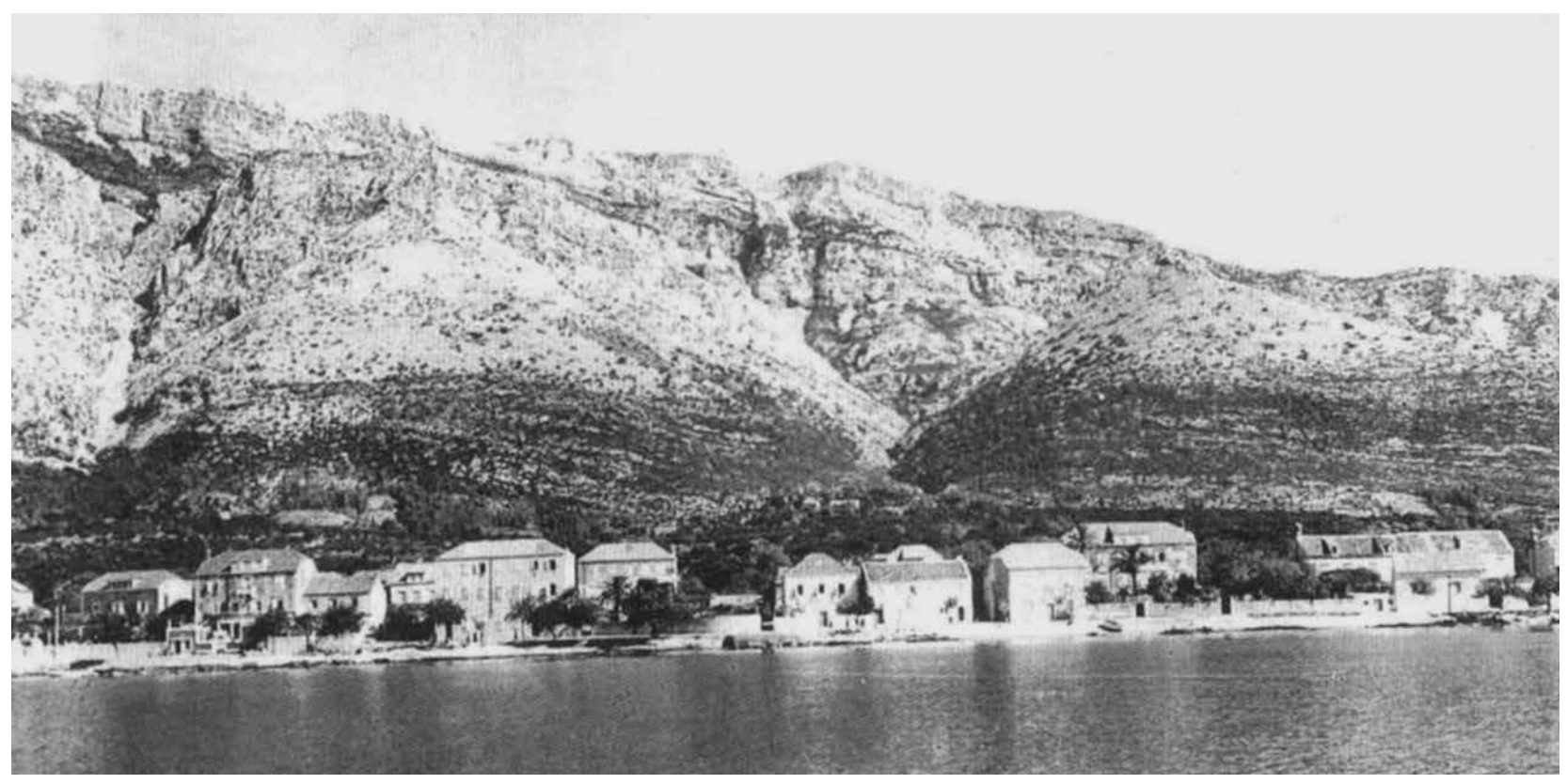

9. Pogled na dio naselja s mora sredinom 20. stoljeća / View of part of the settlement from the sea, mid-twentieth century

Svakako su unutarnje geometrije ravnomjerne vanjski$\mathrm{ma}$, te se u međuovisnosti skriva iluzija o veličinama jačim nego što postoje, a otkriva sklad rezidencijalne arhitekture koja se uz skučeni rječnik oblika fragmentarno doticala zakonitosti bez dubljeg utjecaja već minule renesanse, a škrto i rijetko navrijeme progovorila duhom barokne ili klasicističke estetike. ${ }^{59}$ Uz tako oskudne pokazatelja stilskih tijekova, tipologija građevno-prostornih struktura postala je dominantna nad stilom učinivši ga slabo značajnim, jer je zacijelo smatran prolaznim. Tome je mahom dosljedan kameni namještaj interijera koji malobrojnošću zidnih umivaonika i kamina nije imao značajnije mjesto, iako treba pretpostaviti da ga nekoć bijaše više.$^{60}$ Uglavnom je opremanje unutrašnjosti dotičnih kuća kao i raščlamba vanjština bilo primjereno društvenom statusu i imetku, te mentalnom sklopu samih vlasnika ne oviseći isključivo o neophodnostima kućnog života. ${ }^{61}$ Koliko pak ta u suštini samoobjašnjiva arhitektura bijaše sraštena sa sredinom, govori činjenica da se uglavnom mala odudaranja od ustaljenih normi nahode na kućama došljaka ili stranaca. ${ }^{62}$ To potvrđuje kako su i unutar općenite standardizacije bila moguća variranja, jer je presuđivala volja vlasnika-korisnika koji su znali što hoće i očekuju neovisno o mijenama političkih vlasti ili svojeg prelaska s jedrenjaka na parobrode. Njihovo se poimanje korisnoga i ugodnoga stopilo s poimanjem ukusnoga, što je podrazumijevalo i sadržavalo sve čimbenike ukupne arhitekturalne obrade.

Međutim, globalnim uzoritostima kuća kapetana i brodovlasnika u Orebićima još pripadaju zajedno s njima osmišljene i uređene okućnice. Pomalo simbolički, no iz jasnih praktičnih razloga, jednovrsne su novogradnje okretanjem jugu osvajale pogled na more, a opkoljavale se prostranim dvorištima.$^{63}$ I koliko god se pažnje polagalo na oblikovanje stambenih katnica ili ulagalo u njihovo opremanje, toliko se nastojalo urediti okućja i vrtove, ${ }^{64}$ te su vlasnici kao zaljubljenici teško stečene svojine, tu trošili dobar dio svoje imaginacije. Ne hoteći mijenjati arhitektonske matrice kuća koje između ostalog sigurno odgovarahu žudnji za mirom pomoraca ogrezlih u putovanjima, a zadovoljavahu opći ukus epohe, oni su težili približno dostići vrsnoće sklopova dubrovačkog ladanja s njegovanim perivojem kao drugom njihovom sastavnicom. ${ }^{65}$ Prigode za nabavu sadnica čak su imali i više krećući se morima do egzotičnih zemalja, pa su to plodonosno i radili uz profesionalna znanja o svugdašnjim klimatskim uvjetima. Obuzeti pak ponosom što su zagospodarili zavičajem, u njemu su stvorili posljednje, makar u naravi mnogo jednostavnije izdanke perivoja renesansnobaroknih ljetnikovaca, prilično značajne i za ukupnu povijest hortikulture primorske Hrvatske. ${ }^{66}$ Njihova je razigrana raznolikost u nekoj mjeri nadoknađivala ono što bi se u prividu arhitekture kuća moglo smatrati nedostatkom, jer je u podlozi i osrednjih kakvoća ukupnih cjelina također bio duh nadmetanja kao neporeciva konstanta važna njihovu uobličenju i skandiranju.

Zapravo su naglašenu reprezentativnost tridesetak kuća u fasadi Orebića dopunili đardini nejednakih veličina zasađeni različitim drvećem. Ključnu temu njihova uređenja predstavlja obrađenim kamenom ozidana i popločana šetnica korta, koja od obale okomito prolazi ravno kroz prostor kao glavni prilaz užoj okućnici. S obje je strane prate arule za sadnju cvijeća, a na njima u pravilnim razmacima poredani tanki kameni stupci dosižu visinu potrebnu odrini s kojom 


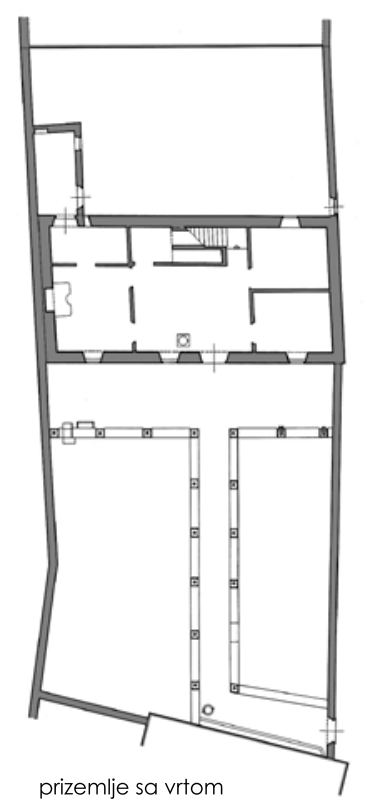

Orebići - kapetanska kuća

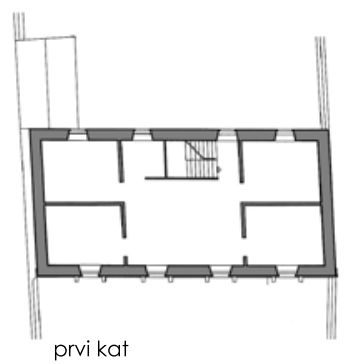

10. Tlocrt kuće Jakulić s vrtom - tipični primjer iz 19. stoljeća (arhitektonski snimak: Institut za povijest umjetnosti, D. Stepinac, 1966., za tisak obradio D. Zuljan) / Plan of the Jakulić house and garden - typical 19th century example (architectural recording: Institute of Art History, D. Stepinac, 1966, graphics by D. Zuljan)

je hodnik korte uokviren i zasjenjen. Uglavnom isti sustav se nastavlja na prikuću, gdjekad zalazi i postrance u slično oblikovano zakućje, koje također omogućavajući lagodnosti boravka bijaše shvaćeno sastavnim dijelom prostora stanovanja, ali razvedeno bez nekih kanona. Dalje se prosljeđuje neizbježni gospodarski dio s od kuće odvojenim prizemnicama za smještaj ljetne kuhinje, konobe i sličnih sadržaja, koji gdjekad zahvaćaju stražnji dio sklopa. Potom se prostiru veće zemljane površine namijenjene poljodjelstvu i voćarstvu, dok su staje za stoku obično povučene uz gornji kraj ansambala koji su u pravilu sa svih strana ograđeni visokim zidom. Raznolike namjene niskih zdanja i nenatkrivenih prostora razumljivo su proizvele razigranosti dojmljivih slikovitosti, protivne svakom unificiranju užeg okoliša kuća koji se objavljuje reprezentativnim gotovo na stupnju ishođenja njihove vanjske i unutrašnje dostojanstvenosti. Uz to je i susret specifičnosti s općenitostima bio djelotvorniji, ali stalno mimo konkretnih stilskih određenja koja bi bila ključ prosudbi vrsnoća tih ostvarenja.

Svakako je varijantama u rješenjima šablonskih sadržaja i vidljivim shemama prostorne organizacije, okruženje stambenih gradnji umanjilo formalne posljedice njihovih kalupa i produbilo im estetsku učinkovitost. Poglavito stoga ih gledamo i cijenimo u čvrstom jedinstvu s njima slijedom stanovitih ponavljanja tema i motiva, to više što su ukupne cjeline za Orebiće postale toliko tipične koliko u nastajanju bijahu karakteristične. Dapače su bez većih međusobnih razdvajanja očito lišene jače kreativne izvornosti, ${ }^{67}$ pa uz

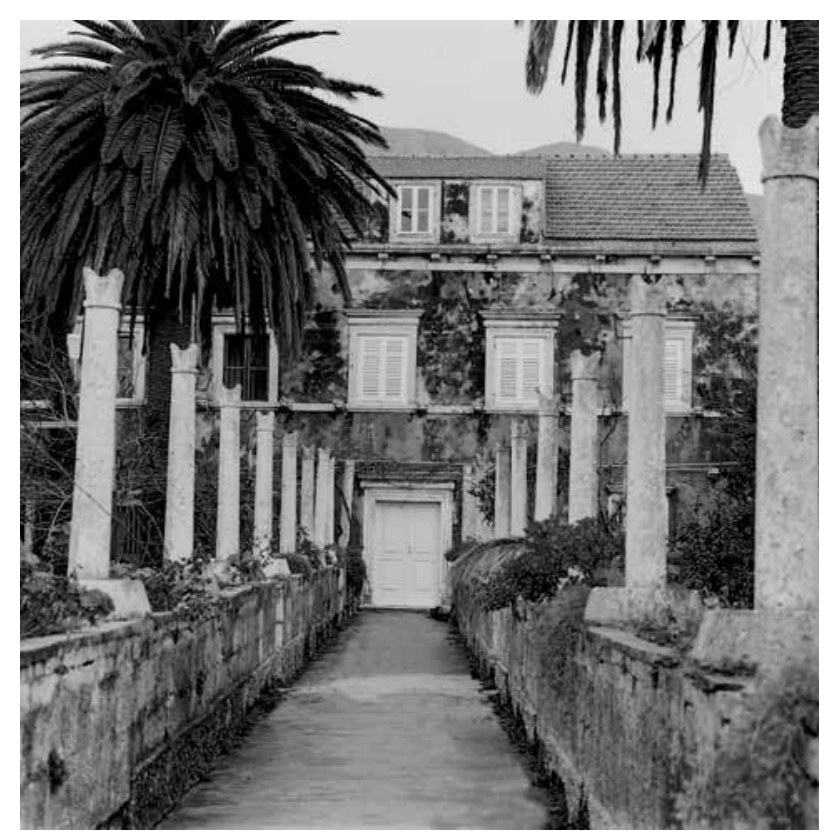

11. Barokna Kuća Bogić s kortom / Baroque Bogić house with yard

svaku im moguću pohvalu moramo ipak držati na umu kako su ishodile iz duhovno ograničenih razina i bile podložne mentalitetu uskih intelektualnih podloga. ${ }^{68}$ Zato na vrijednosnoj ljestvici povijesnih dobara primorske provincije ne zaslužuju neko naročito visoko mjesto, ali im ga uzdiže količinska opstojnost u naselju koje su njihove formalne danosti učinile unikatnim. Prema toj i takvoj zbilji vrednuje se i oblikovna iznimnost njegove pitome cjeline koja nema puno značenje grada, dočim se život tu odvijao stapanjem seoskih i malogradskih vidova ponašanja u prostoru, ujedno suzbijanjem raskola između ruralne i urbane svijesti ljudi. A koliko se ta gorda cjelina uklapala u krajolik uzbudljivo zakriljen kamenim brdom, ${ }^{69}$ toliko rezidencijalna arhitektura sa svojim prirodnim okvirom bijaše hvaljena i od iskusnih stranaca. Sve je to bilo povodom da joj se do sredine 20. stoljeća još nenarušeni izgled pravodobno stavi pod zakone o zaštiti kulturnih dobara s naglaskom na očuvanju naturalnog prostora minuciozne krajine.

U potpunosti te slike diskretno pri moru sudjeluje desetak manjih kuća zasebnoga tipološkog razreda. Značajnije su dvije sažele žargonsku ikonografiju glavnog tipa kapetanskih, a po veličini i opremi mogle bi se smatrati primarnima, s obzirom na doba nastajanja radije embrionalnima. ${ }^{70}$ Minuciozne dvokatnice uskih pročelja a dvaput dubljih tijela položenih smjerom od juga prema sjeveru, ozidane kamenom i neožbukanih fasada vrh kojih dominira svjetlarnik na krovu, uznose htijenje da se pokažu na pozorničkome licu Orebića. K tomu nemaju vrta nego samo visokim zidovima zatvoreno prikuće, kratko te široko koliko i kuća. Naprijed im je isturen niski orsan za zimsko sklanjanje brodica, na kojem su ravne terase kao odušak prostora 


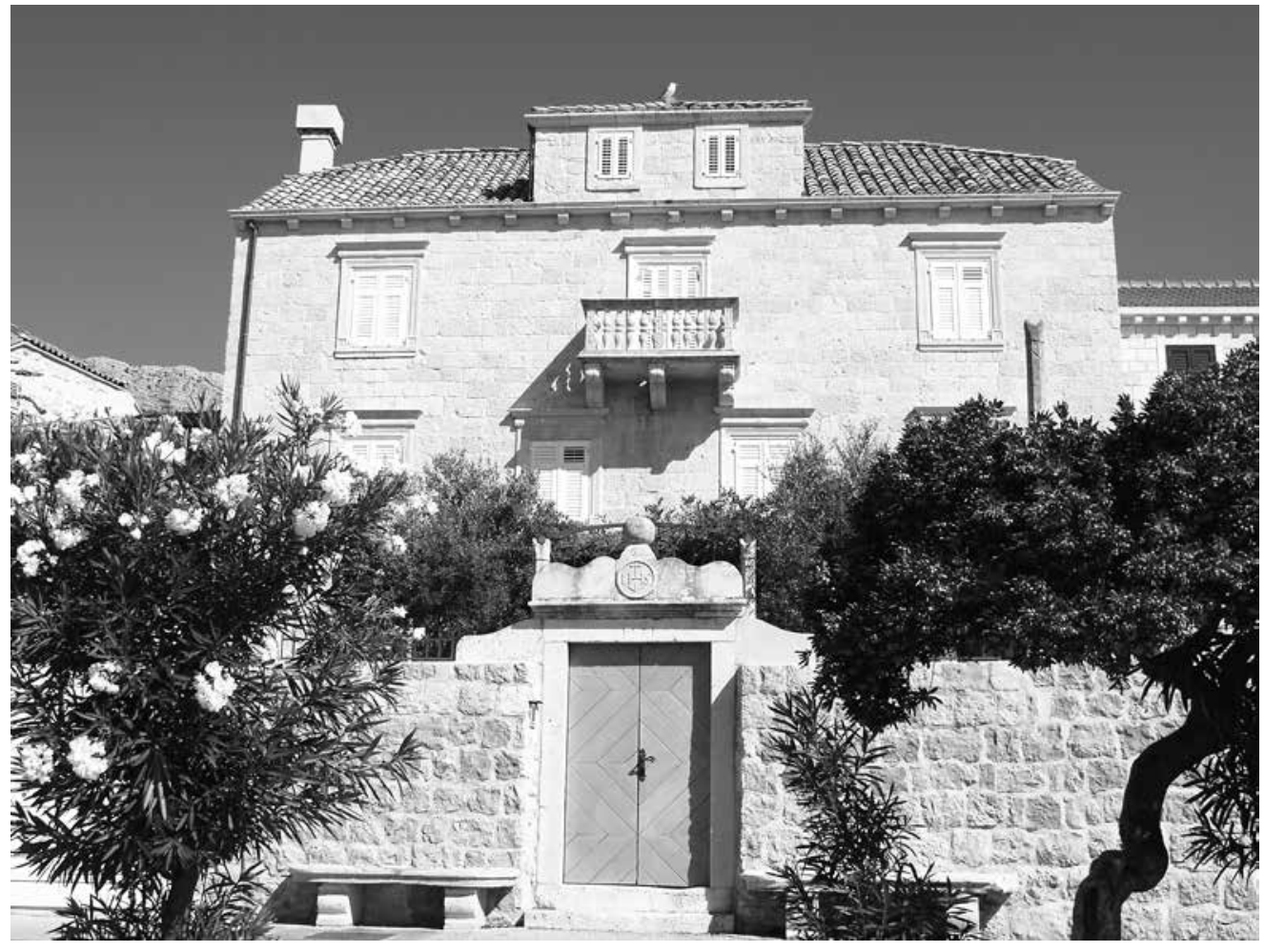

12. Kuća Župa građena 1797. godine / Župa house built in 1797

i vidikovac spram mora ali i najsunčanije mjesto za sušenje voća i sl. ${ }^{71}$ Jednostavno uobličujući neophodnosti lokalnog življenja dotična zdanja poštuju zakone ravnoteže i simetrije, izražene odnosom članova prema stambenoj katnici, a naglašene uzanim prilazom kompaktnome sklopu. Značenje im uvećava činjenica da su se istovjetna arhitektonska rješenja s po dva orsana-terase naredala pred manjim kućama u obližnjem Kučištu, pa varirala u narednome Vignju, također pomorsko-kapetanskih predaja i iz njih izlučenih obilježja pelješko-dubrovačkoga graditeljstva, a lokalno određene prostorne organizacije naselja na rubu mora. ${ }^{72}$

U Orebićima ih slijedi najkasniji tip svjetovnoga graditeljstva nastao umetanjem manjih kuća u ograde korisnih i ukrasnih vrtova, slijedom diobi imanja i umnažanja broja pomoraca. Unatoč potpunim tradicionalnim strukturama slijed vremena učinio je svoje te su im pojednostavljeni, zapravo ogoljeni klesani okviri otvora, što će dati pečat većini zgrada od sredine 19. stoljeća. Neke su se od tih kuća smjestile na uglove kičme naselja s uličicama prema površinama terena u pozadini promičući nova urbanistička poimanja vezana s povećavanjem Orebića. Sustav njegove tlocrtne i volumetrijske raščlambe tada je svrhom komunalnih potreba dopunilo nekoliko prizemnica uz uzdužnu prometnicu namijenjenih dućanima za najnužniju opskrbu. Konačnu je riječ dala skupina malih jednokatnica Beleševa sela, zbijenih poput onih iz primarnih faza izgradnje, ali položenih usporedno s rubom obale bez dvorišta i vrtova.
U dva niza između ulica upriklađene su zadružnome življenju, ${ }^{73}$ a po škrtoj frazeologiji oblikovanja očito pripadahu siromašnijem staležu svjedočeći kako se klasno-imovinske diferencijacije ogledahu u arhitekturi baroknih zametaka. Bez obzira na kronološki nečitki odnos te svojevrsne podgrupe prema djelima glavnog tipološkog razreda što je definirao fizionomiju Orebića, ona skupa s prva tri navedena "zaselka" predstavlja sporednu liniju mjesnoga graditeljstva ističući morfološku vrijednost i povijesnu autohtonost kuća područne "pomorske aristokracije«. ${ }^{74}$

Za potpunije razumijevanje tih vrsnoća bit će dovoljno upozoriti kako su prva reprezentativna zdanja izravno komunalne namjene - nevelika palača općinske uprave iz 1845. godine, kao i nekoliko desetljeća mlađa matična crkva obnovljene Župe, ${ }^{75}$ škrto sazdane u neostilovima 19. stoljeća. Njihov je duh sveden na neprimjereno pročišćeni govor arhitekture bez osjećaja za klesane potankosti, te se projekti očito stranoga postanka nisu organički uklopili u ambijent, iako su rađeni po mjeri već dostignutih izričaja građanskoga gospodstva. Naprotiv je vrlo znakovito istodobna zgrada središnjice naglo uzdignutoga a brzo propaloga Pelješkoga pomorskog društva osmišljena nalik kapetansko-brodovlasničkim kućama uz blage primjese pomodnog klasicizma. ${ }^{76}$ Sukladno namjeni, pak, obje su svjetovne zašle na žala sučelice prvobitnoj jezgri gdje jedino bijaše preostalo mjesta, te pomaknuvši frontu dijela naselja proširenjem uzdužne prometnice formirale poluotvoreni trg. Nedaleka 


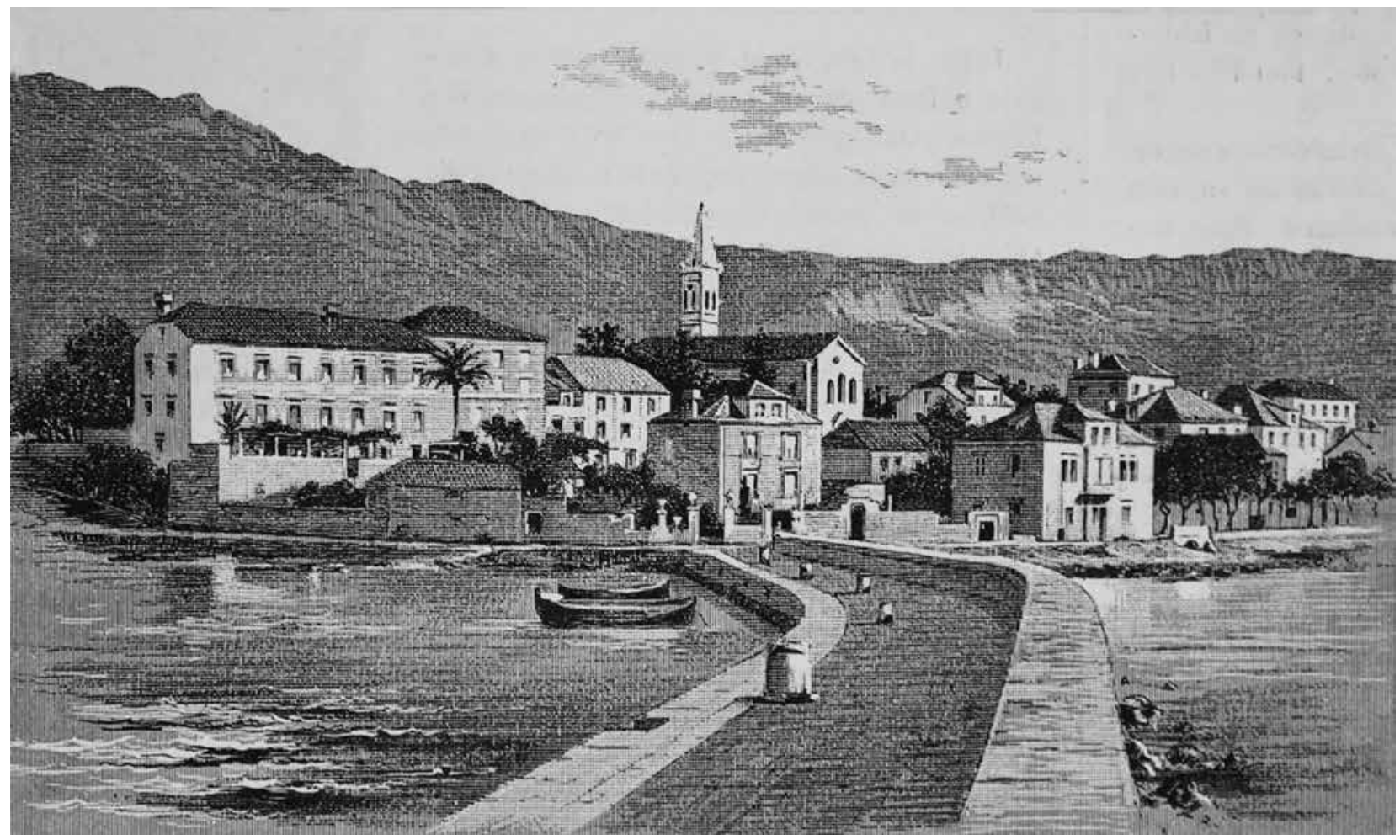

13. Grafički prikaz zapadnog dijela naselja / An old print showing the western section of the settlement

je pak crkva povučena u tkivo već proširene zone stanovanja na malo povišenome terenu sa sjeverne strane dopunila arhitektonsko okupljanje Orebića poremetivši mu osnovnu protegnutost. ${ }^{77} \mathrm{No}$, zajednički im je učinak u tome što su u doba pojačanih zahtjeva političkih uprava za ustrojavanjem prostora javnoga života stvorile urbanistički, dotad nepostojeći centar. Vezano s njime manje se preustrojavanje zbilo $s$ gradnjom dugačkog, $u$ more isturenoga gata, ${ }^{78}$ zamjenu za luku jedrenjacima koju se zbog plitke i pjeskovite obale ovdje nikada nije moglo formirati. Zauzvrat se u osi gata na položaju prvotnog Štukova sela-prikuća okupio grozd većih kuća u tom trenutku najmoćnijih obitelji, koje kao da dočekuju putnike s pristaništa jedrenjaka i prvih parobroda. No, glavnina kapetansko-brodovlasničkih domova nijednom se od tih urbanističkih zahvata nije posvema podredila u vizualno-plastičkome smislu, nego su panoramski još i ojačale svoju nazočnost u stoljetnoj ravnoteži s vrtovima.

Promišljanja o svim tipiziranim kućama privatnog stanovanja kao najizražajnijim rezultatima ljudskog stvaralaštva u danoj sredini, ${ }^{79}$ na kraju vuku pitanja oko njihova projektiranja. Držeći naime nedvojbenim da su bile plod narudžbi samih korisnika i vlasnika, investitora iz elitnoga sloja zajednice živuće u osobitim prilikama, valja podsjetiti ako ne na slabo nam dokučivi kulturni habitus, ${ }^{80}$ a ono na racionalno ponašanje $u$ glavnini djelatnosti tih ljudi. Zaista, od upravljanja stečenim zemljoposjedima koje su okretali proizvodnim granama što sigurnije dobiti, ${ }^{81}$ preko rukovođenja jedrenjacima duge plovidbe i njihova usmjeravanja putovima svjetske trgovine ili konjukturama strane privrede, oni su itekako dobro znali što znači red protivan ikojoj slučajnosti. ${ }^{82}$ Po tom su iskustvu podigli dična djela svoje rezidencijalne arhitekture, građenje kojih su morali povjeriti zidarskim majstorima a njihovo opremanje drugim zanatlijama, ${ }^{83}$ te se $s$ grananjem uslužnih djelatnosti povećavao broj pučanstva. Orebići su sa svime time dočekali zadnju etapu drugog tisućljeća održavši postojanost životnih harmonija u stranim zemljama školovanih zapovjednika i časnika jedrenjaka s obzorjima ovdašnjih njihovih predaka.

Svi su se ti Orebićani naime po usudu svoje profesije "nagledali svijeta ${ }^{84}$ ali se poduzimajući navedene gradnje kao temelj životne sigurnosti nisu razumom i duhom odricali zavičajnosti. Budući da takva bijaše većina kuća u doba najjačeg podizanja opisanih zgrada, za dublje spoznavanje njihove samosvojnosti slobodno ih je usporediti s jedrenjacima, jer to bijahu dva pola ponajveće pomnje tih ljudi. Pretežna su se njihova nastojanja za osiguranjem doličnoga opstanka upirala u građenje obiteljskih domova kao statične te u pomorstvo kao dinamične linije osobnog potvrđivanja. U prilog pak njihova ravnovjesja vrijedi zapaziti kako međusobno razdvojene stamene kuće u vrtovima podsjećaju na lađe u mirovanju na sidrištu, pa se po toj predodžbi smije razabrati i psihološku osnovu postignuća koja smo uznastojali problemski rasvijetliti. ${ }^{85}$ Naravno, o jedrenjacima se više ne govori - njih su davno raspremili i trupovi su im 


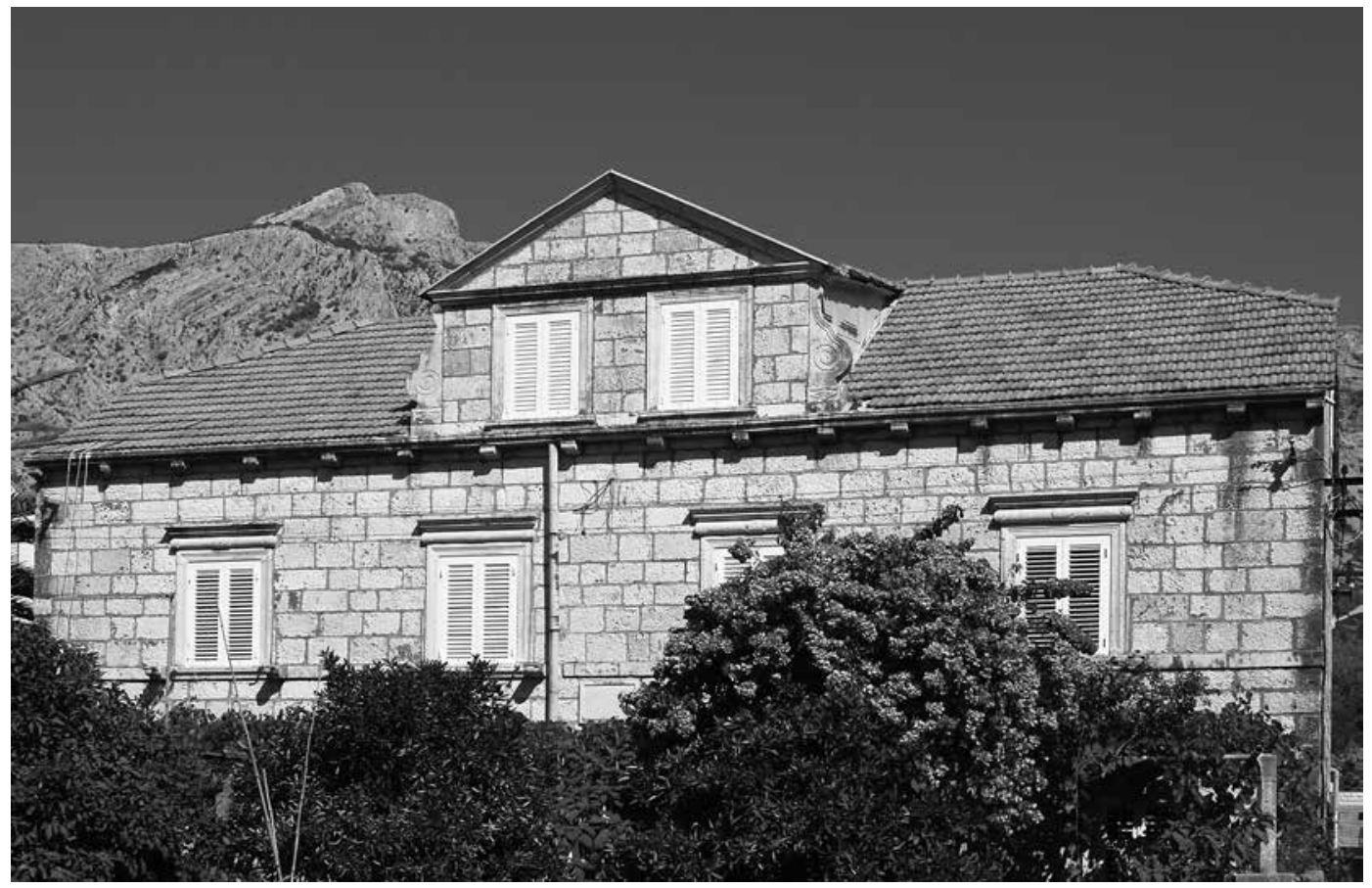

14. Pročelje kuće Kovačević sa završnim svjetlarnikom / Front of Kovačević house with a dormer

sagnjili, a i parobrodi su iščezli, no kuće s vrtovima u dijalogu $\mathrm{s}$ blistavim podnebljem juga još zauzimaju svoja mjesta $u$ pitomome prostoru kao stjecišta odmora i užitka. ${ }^{86}$ Nismo ih uspoređivali s izvangradskom arhitekturom iste svrhe iz ostale hrvatske obale, ali nema sumnje da bi se time bolje očitovale istinske im vrsnoće iznimne naravi ${ }^{87}$ jer je bila riječ o združivanju stambene i ladanjske kuće. Potonju je pak komponentu nametnuo prirodni okvir Orebića, a i korijeni tipa u ljetnikovcima dubrovačke gospode, ali kultivirani sklop kuća i vrta tu nipošto nije »ljetnikovac«, kako ga se gdjekad naziva. Istina je naime da oni obuhvaćaju čitav niz funkcija kontinuiranog življenja ${ }^{88}$ umjesto same razbibrige i užitka što su sebi priuštavala vlastela. To se, između ostalog, odrazilo i u odnosu zgrada i vrta, jer su orebićke kuće redovito pozicionirane usred njega: doslovno zaposjedaju čitav teško stečeni i ljubomorno čuvani privatni prostor, dok su se »ljetnikovci gospara u unaprijed im zajamčenoj očevini bez pravila češće ležerno raspoređivali, pa je vrt ili perivoj tvorio zasebni entitet kako ovdje nije bilo. ${ }^{89}$ Vrh svega, kuće koje su predmet našeg ogleda u svojoj srži upliću i antitezu pomorcima od mladosti na lađama nužno usađenog asketizma te kroz generacije ukućana do razine častoljublja odnjegovanog ponosa. Dakle je iz složenih, dobrano ideološki obilježenih a ekonomski uvjetovanih empirija ${ }^{90}$ satkan mikroregionalni identitet pučke arhitekture, koja u zbiru sinkronih različitosti svekolike stambene s čitavog uzmorja, zaslužuje priznanja. Ona su pak uistinu nepravedno izostala negdje na razmeđima zanimanja ili znanja etnografije i naše struke, dok se o "narodnoj « - razgovjetnije seoskoj bez pejorativnog značenja - puno više analitički pisalo. ${ }^{91}$

Zacijelo bi bilo posve neobično da su se naručitelji rezidencijalne arhitekture i davatelji sredstava za njezine gradnje prepustili pukoj umješnosti samih izvršitelja s time skopčanih radova, koji nisu iziskivali neka posebna znanja. ${ }^{92}$ Pogotovo uz činjeničnu sličnost među orebićkim kućama iz glavnoga njihova razreda, svi su izgledi da su im oblike smišljali oni koji su ih namicali za sebe spoznavši kakva im rješenja ponajbolje odgovaraju da zadovolje široku prizmu svojih odnosa prema stvarnosti. Drugim riječima: ako i nisu bili "projektanti« u užem smislu riječi, od početka ustrojavanja Orebića kakve još gledamo, pomorci su imali vodeću ulogu pri promišljanju leksika i sintakse glavnine oblika svakoga toga djela. ${ }^{93}$ Naravno, s time im se ne pripisuju dublje upućenosti u tehnike i tehnologije graditeljstva, ali smo više nego blizu uvjerenju kako odani tradicionalnim shvaćanjima ili skloni konzervativnim nazorima, bijahu odlučni za izbor i tipologije cjeline i glavnine elemenata njezine razrade, dok su oblikovno gotovo šablonske kuće zidali osrednji majstori na raspolaganju u užoj sredini. ${ }^{94}$ Ona je dakako s pratećim pojavama i ustanovama koje utjelovljuju razne djelatnosti, poprimala sve značajke modernoga gradića, te su Orebići 1908. godine i službeno dobili statusni naslov grada, središta upravnog i sudbenog kotara zapadnoga Pelješca. ${ }^{95}$

Razumljivo su ostale kuće za razne niže kotirane staleže ili uvjetno priprosti puk bile izgledom siromašnije, formalno bliže skromnim zemljoradničkima, a dobrano skrivene položajem nimalo konkurentne u svemu nadmoćnima, pripada- 


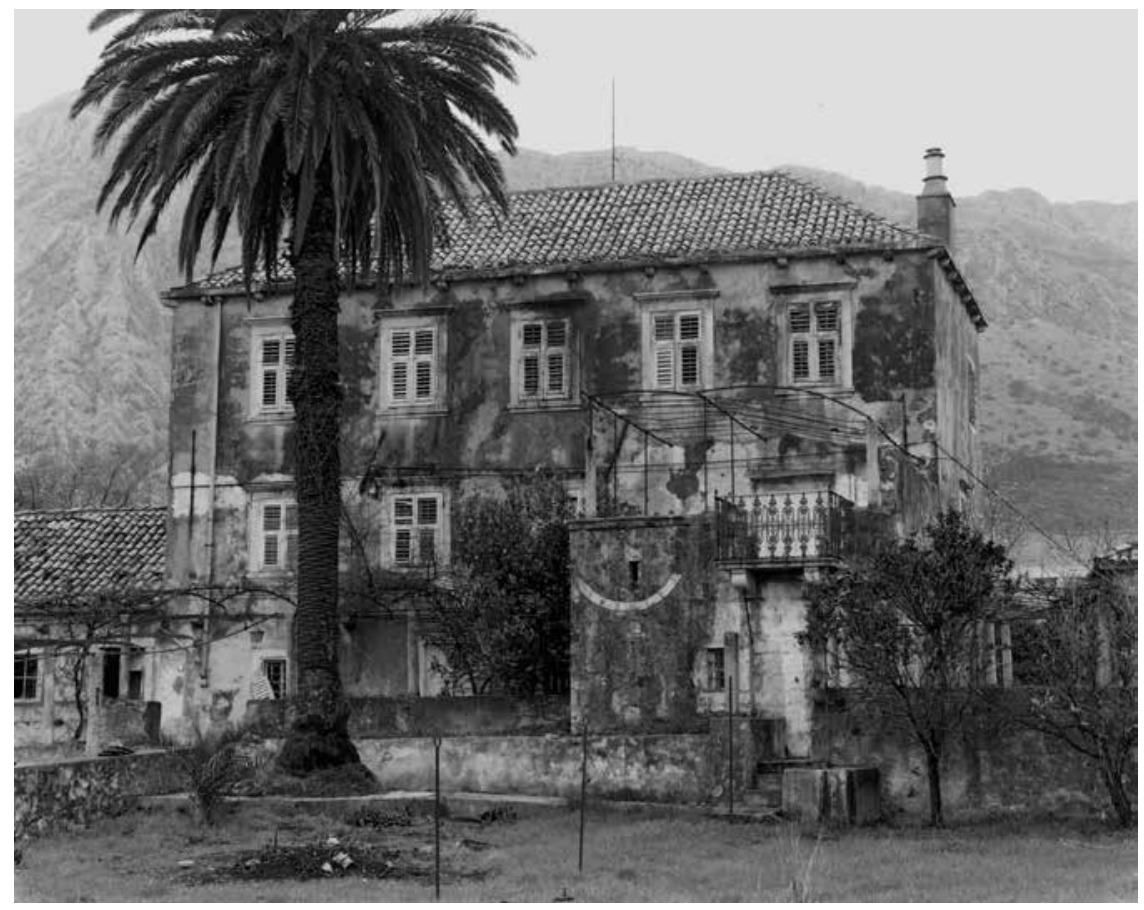

15. Kuća kapetana Joza Šunja iz 19. stoljeća / Captain Jozo Šunj's house, 19th century

jućima dobrostojećem kadru kapetana i brodovlasnika. Ipak se iste kompozicijske sheme ponavljaju i na ponekoj posve šturo oblikovanoj kući, podizanje kojih iz mladosti pamte još živući ljudi izravno pokazujući koliko je dugo tradicijska tipologija bila djelotvorna s malo odmaka od prekaljenih predaja i navada. ${ }^{96}$ Ako je njih nadasve obilježilo kasnobarokno doba, to nam uz neosporne čimbenike tadašnjeg stila ipak ne daje prava Orebiće cijeniti ishodom konkretno pročišćenoga stilskog ukusa, pa radije govorim o sumi hibridnih, u suštini provincijskih oznaka. Na toj osnovi slabe i usporedbe sa suvremenim materijalnim dosezima kulture stanovanja $\mathrm{u}$ čitavom jadranskom primorju, što je i u prikazu jedne vrste arhitekture u uskome području prouzročilo suzdržanost oko pitanja njezina formalno-stilskog opredjeljenja. No, u plastički živoj slici naselja s povijesno mu danim atributom gradića, gore tek tipološki predstavljene stambene gradnje su ostale dominantne, posve do sredine 20. stoljeća, a u znatnoj mjeri i do danas. Dakle nas mnogo razloga nuka i potiče stare kuće pomoraca u Orebićima vrednovati kao osobiti domet i samosvojni model na širokoj pozornici povijesnih dobara i kulturnih izričaja južne Hrvatske.

\section{BILJEŠKE}

1 Ime pišem u pluralu kako se odavno činilo naprosto zato što su Orebići formirani od više manjih naselja. Skupni im je pak oblik u singularu stvoren tek u doba austro-ugarske uprave kad službeni jezik bijaše talijanski koji ne trpi pluralne oblike u nazivima pojedinih naselja. Iako je tada zapo- stavljeno ime trajno održavala većina znanstvenika ili spisatelja, pa su ga bila obnovila i hrvatska enciklopedijska izdanja 20. stoljeća, nažalost, jači je bio pritisak moderne administracije uz opće gašenje tradicija i zanemarivanje povijesnih izvornosti, te naziv Orebić danas prevladava.

2 Držimo na umu da je isti tip privatnih kuća pomoraca kao ključ spoznajama o gospodarskim i društvenim prilikama, a i prostornoj organizaciji na zapadnom Pelješcu, dominantan u obližnjim obalnim naseljima nejednakih veličina Kučištu i Vignju, ali primjeri u Orebićima prednjače po svojoj reprezentativnosti. Globalne sam odnose među njima prvi put apostrofirao cjelovito u knjizi IGOR FISKOVIĆ, Kulturno-umjetnička prošlost Pelješkog kanala, Mogućnosti, Split, 1971., u prikazu stanja baroknog, te kasnijih razdoblja, a inače se o njima nije pisalo.

3 U tom kontekstu nije moguće sa sigurnošću datirati i locirati podrijetlo tipa, ali valja naglasiti koliko je s primjernim inačicama dokaziv u užim predgrađima samoga Dubrovnika, jednako u naseljima Dubrovačkog Primorja i Župe, te na Elafitima, u manjoj mjeri na Lastovu i Mljetu, pa ga smijemo smatrati dubrovačkim modelom. U 19. stoljeću se pak uvriježio uglavnom po polugradskim naseljima diljem čitave južne Dalmacije, a drugdje znatno slabije.

4 Poglavito se time razlikuju od vlasteoskih ljetnikovaca, kao starijeg sloja izgradnje u slobodnom prostoru širega dubrovačkog okružja - NADA GRUJIĆ, Prostori dubrovačke ladanjske arhitekture, Rad JAZU, 399, Zagreb, 1982.

5 Primarnu sam njihovu registraciju obavio za potrebe PUP-a Orebić 2009. godine (Odjel za urbanizam Arhitektonskog fakulteta u Zagrebu), slijedom kojeg su zaštićene kao cjelina ambijentalne, ali ne i spomeničke vrijednosti.

6 U vezi s time valja nam odmah istaknuti kako se u njemu razvila jedna prilično samoživa zajednica, kulturološki to privlačnija što je stoljeća prebrodila iznenađujuće uspješno bez ikojega jačeg utjecaja izvana.

7 Došavši mirnim putem sredinom 14. stoljeća dubrovačka je uprava organizacijom administrativne jedinice Trsteničke kapetanije sa sjedištem pokraj najstarijeg sijela crkvene župe, pokrenula preobražaj koji je odredio statičnost života u prostoru presudnu urbanizaciji ma kako god škrta bila. Znakovito je da su se glavni njezini tijekovi usmjerili na pojas obale koji su nekoć držali Rimljani - IGOR FISKOVIĆ, Pelješac u protopovijesti i antici, Pelješki zbornik, I (1976.), 15-80, a ilirski starosjedioci su još 
u prapovijesti nastavali zone koje je pod brdom bio jače operacionalizirao srednji vijek s poljoprivrednim, zadugo održanim zaselcima gdje su usporedno s ovima nastajale slične ali manje kuće.

8 CVITO FISKOVIĆ, Naše urbanističko nasljeđe na Jadranu, Zbornik društva inženjera i tehničara u Splitu: 1958., (ur.) Slavko J. Sirišćević, Split, 1958., 45-60.

9 Prirodne odlike detaljnije iznosi V. poglavlje knjige Južno hrvatsko primorje - Geografija Hrvatske, 6, Institut za geografiju Sveučilišta u Zagrebu, Zagreb, 1974., gl. V.

10 Zapravo se ta granica u odnosu na ovdašnje prilike pokazala permanentno labavom s obzirom na to da je Korčula bila Serenissimi važnija u globalnoj strategiji na Jadranu i prema Levantu, a zapadni je Pelješac udaljenome Dubrovniku bio u interesu poglavito zbog privrednog iskorištavanja koje nije vodila državna uprava nego ga je prepustila vlastelinstvu, dok je u oligarhijsko-aristokratskom svojem sistemu upravo njemu generalno čuvala teritorij.

11 Nakon pada Dubrovačke Republike 1807. godine tu je nakratko nastupila napoleonska vlast, a potom se duže od jednog stoljeća ustalila austrijska uprava. Potonja je bila najutjecajnija, a ravnomjernosti unutrašnjeg razvoja pridonijela je i činjenica da pelješki prostor nisu izravno doticala nikakva ratna zbivanja od kojih je, međutim, dosta šteta trpjela pomorska djelatnost izazvavši oscilacije u ritmu razvoja graditeljstva s najvišim dosegom u 19. stoljeću, kad je porast broja žitelja odredio prostorno širenje priobalnog naselja u granicama koje će se održati sve do zadnje trećine 20. stoljeća.

12 MARIJA PLANIĆ-LONČARIĆ, Planirana izgradnja na području Dubrovačke Republike, Centar za povijesne znanosti, Odjel za povijest umjetnosti, Zagreb, 1980.

13 Dokumenti iz 14. stoljeća spominju planiranje jedne nastanjene fortifikacije na položaju Vignja, u tjesnacu prema otoku Korčuli, ali nije ostvareno, pa ostaje tek zabilježba o naumu utvrđivanja Pelješca preko puta korčulanskom gradu pod mletačkom upravom. Na strateški ključnome mjestu taj je zadugo ostao jedina utvrda, važna za kretanje brodova, a bez učinka na odnose s Dubrovnikom koji je nakratko u svoje ruke čak bio dobio otok Korčulu do 1420-ih godina, tako da rast prvotnih Orebića ne utječe na međudržavnu politiku koliko na zbrinjavanje poluotočkog stanovništva.

14 Riječ je o regulaciji Prijekoga iz 1284. godine kao nove četvrti koja zauzima sjevernu polovicu grada - MILAN PRELOG, Urbanistički razvoj Dubrovnika, Radovi Instituta za povijest umjetnosti, 1-2 (1972.), te o zapadnom dijelu Stona, drugačijem od preostaloga većeg dijela 1334. godine zasnovanoga plana grada - IGOR FISKOVIĆ, Ston u svojem prirodnom i povijesnom prostoru, Arhitektura, 160-161 (1977.), sa starijom literaturom.

15 Naime, kako se vidi na priloženome tlocrtu iz dokumentacije zagrebačkog Instituta za povijest umjetnosti, sve ulice nisu jednako široke niti su blokovi jednako dugački, što je valjda rezultat nejedinstvenog zahvata. $\mathrm{K}$ tomu je očito da su se ulice prema moru pravilno zatvarale, a prema brdu završavale sa zgradama za stoku u poretku koji tumači prvobitno jaču vezu s agrarom pod gospodstvom onih kojima je čitav Pelješac raspodijeljen sredinom 14. stoljeća.

16 Ne treba zanemariti da je taj sustav rano realiziran i u susjednoj Korčuli - CVITO FISKOVIĆ, Za urbanističku cjelinu Korčule, Mogućnosti, 1 (1955.), 35-41 - dok ga cjeline ostalih obalnih gradova nemaju. $17 \mathrm{~K}$ tomu se sred naseobine diže povisoka kubična kula na kojoj je u medaljonu uklesana 1586. godina, a druga je niža i mala kula stršila na jugoistočnome uglu. Glavna je na vrhu imala krunište od kojeg su ostale same konzole, a upisana godina se vjerojatno odnosi na neku obnovu jer položaj središnje utvrde na stijeni nad izvorom žive vode upućuje na starije postanje. Po nekim vrelima obnova se te kule odvila iz sredstava obitelji Orebić, koja će poslije dobiti naslov plemića, pa ne bi trebalo sumnjati u njezin ugled zahvaljujući kojem je imenovano glavno naselje stare kapetanije i župe Trstenice. Prednja i postrana kula s vremenom je izgubila značenje te je pretvorena u malu kuću kao što je i većina otprve stambenih doživjela nemale preinake, tako da se samo rijetkima razaznaje izvorno oblikovanje ne prije od 16. stoljeća.
18 Cjelina je u neko doba dobila ime "Geta« jer svojom zatvorenošću podsjeća na četvrti starih gradova Europe određene stanovanju nacionalnih zajednica odvojenih od ostaloga građanstva, što ovdje nipošto nije slučaj.

19 Brojni se identični nalaze u gradu i okružju Dubrovnika a malobrojniji i u Korčuli - koja je građena više po mletačkoj gotičkoj modi. Budući da ih sjevernije uglavnom nema, opravdano ih je barem do potpunijih statističkih propitivanja smatrati svojinom kamenoklesarskih radionica iz domaćega ovdašnjeg okruženja po rječniku stila iz 16. stoljeća.

20 Temeljno o orebićkom pomorstvu vidjeti: STJEPAN VEKARIĆ, Pelješki jedrenjaci, Mornarički glasnik, Split, 1960.

21 Naziv po običaju stječe prema brojnosti domaćinstava toga prezimena, ali oni nisu jedini stanovnici.

22 Lokalni naziv za neveliki dvorišni prostor ispred kuća, popločan a u pravilu omeđen niskim zidićima arula za sadnju ukrasnih biljaka. Redoviti su i kameni stupci s odrinama u formaciji poznatoj diljem dubrovačkog područja - CVITO FISKOVIĆ, Kultura dubrovačkog ladanja, Mogućnosti, 3 (1966.), sve preuzeto iz vlasteoskih ljetnikovaca.

23 Dakle se donekle ponavlja primjer kuće-kule iz najstarije jezgre naselja kojoj više ne znamo točni izgled. Shodno pak svojem obliku, ova je gotovo simbolično pripadala obitelji Kerša, povezanoj s gradom i kulturom Dubrovnika. O njima i ostalima iz ovdje spominjanih toponima: NENAD VEKARIĆ, Pelješki rodovi, sv. I-II, Zavod za povijesne znanosti Hrvatske akademije znanosti i umjetnosti, Dubrovnik, 1992.

24 Osim njih, kao i u starijoj jezgri a i diljem čitavog Orebića, sagrađen je do sredine 20. stoljeća mali broj kuća koje zbog slabo izražajnog i neutralnijeg oblikovanja izmiču svim tipološkim razredima, pa o njima ne govorimo.

25 Prvo je sa zapada odredilo granicu nastavanja, drugo bliže staroj jezgri omeđilo raspone izgradnje prema brdu.

26 Svakako je opasnost od pljačkaša s mora koji dolažahu do 19. stoljeća, uvjetovala bar neke elemente poretka.

27 To je prežitak arhaičnih modela iz primorskih gradova, gdje je zbijenost kuća uz tijesne ulice zbog oskudice prostora, kao i usitnjene parcelizacije građevnih čestica, izazvala postavljanje kućnih stuba izvan njihova volumena. Dubrovački statut ih je zabranjivao kao privatnu uzurpaciju javnih prostora, a zbog sličnih odredbi nisu učestale u gradovima duž obale koja ih klimatski omogućava pa su svojstveni ruralnom graditeljstvu - A. FREUDENREICH, Kako narod gradi na području Hrvatske, Republički zavod za zaštitu spomenika kulture, Zagreb, 1972. - kojem se obraćalo više pozornosti nego pučkom u kategorijama koje se ovdje predočuju.

28 CVITO FISKOVIĆ, Naši graditelji i kipari XV. i XVI stoljeća u Dubrovniku, Matica hrvatska, Zagreb, 1947., dokumentira eksport takvih iz Korčule u Dubrovnik, no zasad nisu otkrivene količine orebićke nabave iz istih kamenoloma i radionica.

29 JOSIP LUETIĆ, Pomorci i jedrenjaci Republike Dubrovačke, Nakladni zavod Matice hrvatske, Zagreb, 1984., i mnogi drugi tekstovi o toj tematici.

30 Sumarno CVITO FISKOVIĆ, predgovor knjige Pelješki jedrenjaci (nav. dj. u bilj. 20), daje znati kako to bijaše povod približavanju kozmopolitizmu ili bar internacionalizmu, što se međutim na građi koju motrimo nije jako iskazalo.

$31 \mathrm{U}$ arhivu se navodi više vlasteoskih imanja. Ogledni je primjer u predjelu Podvlaštice kraj sela Stankovića negdašnja sezonska kuća Sorkočevića, a tragova im ima i drugdje iako su ih iskorijenila kasnija doba. Bolje sačuvani ljetnikovac iste obitelji je sred predjela Trstenice u Orebićima, gdje na više kuća ima oznaka gradnji namijenjenih povremenom prebivanju aristokrata, pa se razabire kako je čitava prostorna krajina bila omrežena sličnima.

32 Usporedi NADA GRUJIĆ, Ladanjska arhitektura dubrovačkog područja, Institut za povijest umjetnosti; Nakladni zavod Matice hrvatske, Zagreb, 1991., i druge tematske studije iste autorice.

33 Znakovito je da se ne povode za posve drugačije tipiziranim zdanjima na posjedima korčulanskih imućnika u susjednoj Lumbardi, nastalih u zasebnim uvjetima te se redom sastoje od jedne kuće-kule i s njome 
spojene dugačke prizemnice gospodarske namjene - IGOR FISKOVIĆ, Stari ljetnikovci u Lumbardi na Korčuli, Kultura ladanja: zbornik radova sa znanstvenih skupova »Dani Cvita Fiskovića« održanih 2001. i 2002. godine, (ur.) Nada Grujić, Institut za povijest umjetnosti; Odsjek za povijest umjetnosti Filozofskog fakulteta Sveučilišta, Zagreb, 2006., 105-130. Takvih pak ima diljem otoka Korčule i očito odaju drugačije životne prilike.

34 Važni su razlozi bili u oslobađanju istočnog Mediterana od turskih pritisaka i stalne nazočnosti gusara nakon ratova povedenih iz Venecije - Kandijski rat 1645.-1669., te Morejski 1683.-1699. - što je skrenulo interese Dubrovčana na trgovinu s Levantom, pa su i Orebićani uvelike prepušteni sami sebi i svojem snalaženju u pomorstvu.

35 Uz ojačano sudjelovanje peljeških jedrenjaka u međunarodnoj trgovini nakon prestanka velikih pomorskih ratova, Orebići su konačno definirali vlastite socioekonomske profile s kojima će u prosperitetu dočekati 20. stoljeće i to se manifestira u nizu pojava od kojih neke, protivno oblikovanju rezidencijalne arhitekture, dokazuju bogatu ali hibridnu lepezu dodira poglavito sa zapadnoeuropskim zemljama izlazećima na razna mora.

36 Bila bi to centurijacija, moguća s obzirom na raspored malih ladanjsko-gospodarskih sklopova kojima su tragovi otkriveni na više mjesta u užem arealu Orebića - CVITO FISKOVIĆ, Arheološke bilješke s Pelješca, Vjesnik za arheologiju i historiju dalmatinsku, LV (1953.), 217-240.

37 Prema moru kao i sa svih strana redovito su podizani zidovi viši od visine čovjeka, što uz naglašavanje vlasništva ide u red općih pravila civilnih gradnji na Mediteranu, vjerojatno vezanih uz nazočnost islama.

38 Tu su sudbinu Orebića tijekom razvijenog novovjekovlja dijelila obližnja dva naselja, Kučište i Viganj, rastući malo poslije u svekoliko sličnim prilikama te podjednako upečatljivih upravo po tipologiji kuća pomoraca a i osnovnoj poluurbanističkoj koncepciji izgradnje bez stabilne jezgre. Drugačiju pak ambijentalnost razvijaju zaselci u pozadini Orebića od Stankovića do Bilopolja, pa premda ostaju obilježeni vezanošću uz polja pod brdom, ponavljaju tipološku suštinu priobalnih kuća svodeći je u manja mjerila i zasebne, reljefom tla uvjetovane a vrlo čedne inačice.

39 Razumljivo su upravo proporcionalne trenutačnoj moći rodova, ali uz neotklonjivu štednju u prilikama kad je more odnosilo mnoge živote, treba računati na faktore ponosa i prestiža tako da nisu redoviti dokaz brojnosti članova obitelji.

40 Tako su braća M. i S. Fisković, J. Orebić te obitelj M. Kovačevića u istoimenom zaselku od sredine 19. stoljeća temeljito obnovili prijašnje kuće i dostigli razmjere palača znatno jačih bokeljskih pomoraca koje se diče razvijenim baroknim stilom.

Od barokne epohe, osim pri uobličenju prostora vlastite krajine, Orebićani se potvrdiše uspješnije negoli dotad na planu svestranijeg prodiranja u kulturno življenje zapadnog svijeta, pa se i njihovo naselje uključilo među razvijenije i naprednije krajeve hrvatskog uzmorja. Tomu nije dokaz samo umjetničko naslijeđe, isključivo unutar crkava namrijeto i donirano od pomoraca, nego i pojave istaknutih pojedinaca i ličnosti javnog života, koji su prodrli u strane zemlje i daleke gradove. Naravno, većina ih se dokazala u plovidbenim pothvatima i prekomorskoj trgovini ili pri vršenju raznih diplomatskih poslanstava i političko-ekonomskih zadataka za Dubrovačku Republiku, ali su neki i na ostalim poljima zaslužili časti izvan južne Hrvatske. Najugledniji su potekli upravo iz najstarijih pomorskih obitelji, a cijelog života bili privrženi Dubrovniku s kojim su misaono i duhovno ostajali povezani jer ga smatrahu jedinom svojom domovinom.

41 Tu su pravodobno svoje istaknute pozicije zauzele kuće najuglednijih obitelji Orebić, Flori-Cvjetković, Mimbelli, a slijed ostalih prati vremena njihova rasta na društvenoj ljestvici.

42 Zapravo strše samo dvije - J. Orebića i S. Ivaniševića, narasle iz prestižnih povoda u odsliku duha vremena, te bi u ukupnom oblikovanju kuća vrijedilo analizirati i taj aspekt: kad je koja obitelj najmoćnija u pomorstvu ili društveno najutjecajnija. Zapravo se i u površnom ogledu stanja spoznaju određena pravila od temeljnoga zapadnoeuropskog da se svi bolje situirani ljudi teže iskazati posredstvom svojeg habitata: SIMONE ROUX, La casa nella storia, Editori Riuniti, Roma, 1982.

43 One su u pravilu ožbukane kako bi se spriječilo loše učinke slanoga slapa mora za zimskih oluja kojima je ova obala naročito izložena, ili umanjilo ljetne prodore sunčanih vrelina. Dapače su vanjštine kuća bile različito bojene i po više puta sukladno vladajućim modama, što je proizvelo iznimne vizualne efekte zbog kojih su od prve četvrtine 20. stoljeća Orebići privlačili nebrojene slikare, koji ih ovjekovječiše u osobitim umjetničkim viđenjima. Nažalost, u naše se doba ta izvorna vrijednost ambijenta često potire neprimjerenim ogoljivanjem stare arhitekture, uglavnom uslijed nametnute banalne i pogrešne teze kako "čitava Dalmacija treba pokazivati svoje kameno lice«.

44 Pruženi nad portalima prema prostoru privatnog vrta naročito uzdižu htijenje za povezivanjem korisnog s lijepim ujedno ispunjajući simboliku iskazivanja gospodstva zatajenu u uskim ulicama gradova južne regije. Najljepši portali slijede uzorno raščlanjene iz grada Dubrovnika kao i Fiskovića sela, a kićenije balkone u rječniku kamenoklesarskih radionica 18. stoljeća s Korčule još imaju kuće Cvjetkovića, Župe i Orebića, te neke manje, dok je s najveći Fiskovića uklonjen pri njezinoj diobi među rođacima na dvije polovice.

45 Znakovit je slučaj kuće Lovra Kosovića, bogatog brodovlasnika uspješnog u eri parobrodarstva, kad je povisio svoju rodnu kuću, te su na prvome katu okviri prozora standardno profilirani za razliku od glatkih na dograđenome drugom.

46 Izbor boja vrlo je različit, od rumenih okera preko učestalih tamnocrvenih, ali ima i svijetlih ultramarina te zagasito smeđih. Kako je riječ o tehnikama površinskog nanošenja nekonzistentnih boja a ne njihova miješanja s malterom, to još vidljiva preplitanja slojeva izazivaju osobitu živost patina, najplemenitijih pri korištenju skupoga kamenog praha. No izvorno je često bila riječ o šarenilu, što je također izgled Orebića činilo jedinstvenim na istočnome Jadranu.

47 Sve su one odlučno uljepšale fasadu Orebića, koja je već 1958. bila stavljena pod zakonsku zaštitu kao cjelina.

48 Uslijed ograničenja količine teksta, ali i neokončanih detaljnih istraživanja te manjka arhitektonskih nacrta, analitičke opise donekle nastojimo zamijeniti izborom fotografija koliko ih je moguće u časopisu objaviti.

49 Tih istaka uopće nema u drugim pelješkim mjestima, a od Orebićima tipičnih ugledom na gradske su neki uklonjeni kad bijahu statički oštećeni u potresu 1962. godine, koji je zahvatio biokovski kraj, ali se ovdje osjetio znatnije nego onaj razorni dubrovački 1667. godine ili kasnijih nekoliko oko Stona, jer je čitavo to područje trusnije od ostale obale.

50 Samo neke od tih cjelina nose u kamenu zapisane datume iz kraja 16. stoljeća - najstariji na kući Fisković-Štuk 1568. godine, ali ih je većina iz dvaju sljedećih kao punoga doba lokalnog prosperiteta.

$51 \mathrm{~S}$ obzirom na to da je blizina Korčule s jakom kamenarsko-graditeljskom tradicijom jamčila vrsnoće pa i leksik klesarija, a oni su u pravilu sami zadavali sintaksu njihova razmještaja, zapravo se arhitektura o kojoj govorimo dosta približava ukusu barokne mode, ali u samosvojnosti stvaralaštva ipak nedostaje elemenata da je proglasimo proizvodom toga stila. 52 Naravno, takva se zadržavaju u oblasti sakralnoga graditeljstva, u prošlosti uvijek superiornog i za stvarni umjetnički razvoj višestruko zanimljivog, sa svega nekoliko djela nazočnog u prostoru koji promatramo.

53 U osnovi se drže krilatice "Quatro stanze un salon, z’e la casa d'un Schiavon« kojom su se Mlečani podsmjehivali kućama građana istočnojadranske obale, premda je to humano logičan i prikladan, gotovo univerzalan sustav kad nisu u igri specijalni zahtjevi i osobita, višestupanjska očekivanja od funkcija ili dojma interijera.

54 Dakle se kao u patricijskim ljetnikovcima s ulogom praktičnoga kućnog predvorja izravno nadovezuje na prikuće u sastavu prednjeg, uglavnom ukrasnog a u manjoj mjeri proizvodno korisnog dvora.

55 Osim što je prizemni smještaj općenito svojstven ruralnim sredinama poradi komunikacije s vanjskim prostorom za razliku od gradova, gdje se iz protupožarnih razloga kuhinje nalaze visoko u potkrovljima kamo je drva nosila posluga. I oprema ovih s visokim kamenim a ne nisko položenim vatrištima od opeke, također spada u osobitosti područja to više što su i njih radili s dozom pompoznosti više baroknoga nego renesansnog duha.

56 Odraz je to mode urbane svjetovne arhitekture i prije baroknog razdoblja, koje ih običava posvuda no ipak najzrelije u dubrovačkim luksuzno gospodskim zgradama privatnog stanovanja: KATARINA 
HORVAT-LEVAJ, Barokne palače u Dubrovniku, Institut za povijest umjetnosti; Hrvatska akademija znanosti i umjetnosti, Zavod za povijesne znanosti, Zagreb-Dubrovnik, 2001., koje u cjelini bijahu Orebićanima prilično poticajne.

$57 \mathrm{U}$ najbogatijima su i okviri unutarnjih otvora kameni s profilima suglasnim vanjskima, dok pokretni namještaj u više izvorno očuvanih cjelina otkriva različitost pratećih sadržaja - očitovanih s klavirima i slikama u znaku općeg iskanja noblesse oblige, a većina balkona upravo uz njih vezana operacionalizira gledanje mora.

58 Iz doba jedrenjaka imaju ih najveća kuća obitelji Orebića sred naselja, Fisković-Štuk iz 16., a Šunja iz 19. stoljeća, te maštovitije sustavljenu pred kućom parobrodara L. Kosovića, s očitim asocijacijama na zapovjednički most brodova.

59 Od potonje su po svoj prilici sljedovali svjetlarnike, inače puno rjeđe u svoj primorskoj arhitekturi iste vrste.

60 Ističe se kamin iz kuće u Fiskovića selu: CVITO FISKOVIĆ, O starim kaminima u Dalmaciji, Bulletin za likovne umjetnosti HAZU, 1 (1981.) - a ostaci manje kićenih zidnih umivaonika i ormara su na više mjesta.

61 STJEPAN VEKARIĆ, NENAD VEKARIĆ, Tri stoljeća pelješkog brodarstva, Pelješki zbornik, 4 (1987.), uvode termin »orebićka aristokracija«, stalno pisan u navodnicima, očito ga i uz rasvjetljavanje osnova bogaćenjima držeći za terminus tecnicus.

62 Primjerne su kuće Ivanišević i Morena, funkcionera Pelješkoga pomorskog društva s kraja 19. stoljeća, koje također imaju niske prozore najvišeg kata kao motiv poznat u stambenoj arhitekturi gradova južnog primorja.

63 Sklopove povezuje uzdužna prometnica kao kičma naselja uz koju su poredani samo na jednoj strani srokom niza kuća, dok su s južne pred njima na žalima spretno oblikovani gatovi za male brodice u posjedu jedne ili više obitelji.

64 Najsloženiji su čak primjeri u okolnim zaselcima - uzorno po broju elemenata u zaselku Karmen pod brdom prikuće Đivović-Bijelića na položaju biranom po pogledu na Pelješki kanal i južne pučine prema Mljetu i Elafitima.

65 Usporediti BRUNO ŠIŠIĆ, Vrtni prostori povijesnog predgrađa Dubrovnika, Hrvatska akademija znanosti i umjetnosti, Zavod za povijesne znanosti, Dubrovnik, 2003., i druge knjige istog autora.

66 CVITO FISKOVIĆ, Vrtovi orebićkih kapetana i brodovlasnika, Orebići, 2005. - opširno i dokumentirano s više aspekata analizira vrsnoće uz bogato ilustriranje građe.

$67 \mathrm{Nju}$ iz kolotečina tradicionalnih shvaćanja nisu pomicali ni pojedinačni uspjesi - primjerice kad su poneki kapetani stjecali plemićke naslove od stranih vladara za pomorsko-trgovačke usluge njihovim državama, a kamoli samostalni i brojniji podvizi drugih pod dubrovačkom zastavom na svjetskim morima.

$68 \mathrm{Na}$ to upućuje niz faktora iz dokumentiranoga povijesnog života, jer je npr. reprezentativni sobni namještaj u više stilova uvožen iz tuđine a oprema kuhinja nabavljana u obalnom zaleđu, jedaći pribor kod ponajboljih proizvođača na zapadu. Mnogo je i dubljih proturječja, jer uz dobru pismenost višeg sloja pomoraca i za trgovinu im nužno poznavanje stranih jezika, žene bijahu mahom nepismene. One su se odijevale pretjerano kićeno, CVITO FISKOVIĆ, Orebićka ženska narodna nošnja, Pelješki zbornik, I (1982.), a muževi po europskim modama, te se za ovdašnje njihovo izvorno jedva zna. Pučko se pak pjesništvo napajalo narodnim iz bliskog kopna itd., te je polivalentnost kulture iznimno zanimljiva a stanogradnji čak protivna.

69 Potvrđuju to putopisi učenih stranaca koji su češće navraćali od 18. stoljeća - dio ih navodi CVITO FISKOVIĆ, nav. dj. u bilj. 66, naglašavajući njihove zanose s općim viđenjima, ali i pronicavo poniranje $\mathrm{u}$ ambijentalne detalje.

70 Vidjeti sl. 11 uz spoznaju kako se bez iole grandioznih težnji ondašnjeg baroka inzistira na otmjenosti eksterijera, te i u čednim dimenzijama s relativno malo sredstava može polučiti prilično dobar učinak.

71 Rješenje je učestalo u Kučištu i Vignju, gdje su priobalne kuće pomoraca manje nego u podaljim zaselcima, gdje ima upravo uzornih struktura pa i više stilski definiranih sklopova - npr. Semunovića u Podgorju.
Uvid u glavninu karakteristika IGOR FISKOVIĆ, nav. dj. u bilj. 2.

Zapravo natprosječno usitnjene kuće realiziraju vrlo specifičnu strukturu jer prvi niz s fasadama izravno izlazi na uzdužnu prometnicu, a u sebi zatvara tijesni nenatkriveni prostor s bunarom, koji drugi sklopovi uopće nemaju. Sa sjevera je drugi red kuća kojima su fasade preko izduljenog prikuća sučelice onima iz trećega reda, koje opet imaju ograđena dvorišta pružena dublje prema polju. Obitelji koje napućivahu zaselak su ribarske i zemljoradničke.

72 Zadržavajući značajke toga atributa malo ih spada inače u 19. stoljeće i na našem primorju sve jačoj kategoriji kuća za unajmljivanje nižim srednjim staležima - općenito o njima: LEWIS MUMFORD, Grad $u$ historiji, Naprijed, Zagreb, 1968., gl. 51 i d. - koje je i ovdje ojačano iz profitnih razloga ali i s umnažanjem činovništva kao posljedicom sve brojnijih državnih ustanova.

73 Crkva s rijetkim titularom »Gospe Pomoćnice kršćana« sagrađena je 1885. godine s prinosima država, koja je valjda pružila projekt građevine, pa i simboličnim carskim donacijama, no u većoj mjeri pomoću milodara svih mještana koji su s time osigurali položaj obiteljskih klupa: bogatiji bliže glavnome oltaru, a siromašniji dalje prema ulazu. No neke obitelji podariše sredstva za zavjetne svoje oltare, među kojima su i neki drveni u neogotičkom stilu iz kontinentalne Europe.

$74 \mathrm{Za}$ ono doba vrlo naprednu udrugu obradilo je više autora u knjižici Pelješko pomorsko društvo, Orebići, 1971. Zbog povođenja za načelima velikog stila zgrada se ističe za Orebiće natprosječnom čistoćom svekolike artikulacije.

75 Zapravo je glavno pročelje svojeg zakonito uzdužnog volumena upravo poput kapetanskih kuća okrenula jugu prema moru, zanemarivši pravilo orijentacije kršćanskih svetišta od istoka prema zapadu. Stoga i to gledamo potvrdom gotovo nezajažljivoga ovdašnjeg htijenja za reprezentativnošću temeljem profanog prakticizma simboličnih korijena.

76 Kao markantni ali kasni urbanistički naglasak sagrađen je 1870. godine, pomaknuvši težište izgradnje Orebića k zapadu, čemu je pridonijela oveće palače Kotarskog suda 1907. godine.

77 Doslovnu kreativnu individualnost na nekome drugom polju nisu ni mogli uputiti, a kamoli razviti jer su živeći na slabo plodnoj zemlji trajno bili okovani prirodnim uvjetima, a ni oblici moderne ekonomije ih nisu privlačili s obzirom na to da u njima uglavnom nisu nalazili sebe. Dakle su po staroj mudrosti iznašli životne mjere is njima bili zadovoljni.

78 Iznimno ga ilustrira knjižnica V. i F. Fiskovića s oko 350 svezaka iz doba prije 1850. godine u kategoriji kulturnog dobra.

79 Maslinarstvo i vinogradarstvo umjereno se intenziviralo kako je od pomorstva i brodarstva rasla gospodarska snaga pojedinih obitelji, a zemljišni se njihov imetak čuvao slijedno drevnoj poslovici: »Kako se rđa od gvožđa lako ne ozdaje, tako ni nema gospodstva gdje ga loza ne daje.» U dijalektu »ozdaje« znači »uklanja«, a »loza« je vinograd. Povjerenje pak u zemlju tipično je dubrovačko, a ovdje ukorijenjeno u činjenici da su žitelji Orebića početno bili kmetovi vlastele iz grada, a tek postupno postajali zemljoposjednici sa svojim kolonima. Ta su složena stanja razlomljena tek s ekonomijama modernog doba, što su bitno smanjila vrijednost zemlji koja nije bila glavni oslonac preživljavanja, pa je u 20. stoljeću uslijedila njezina rasprodaja izazvavši priličan nered u nasilnoj urbanizaciji naselja.

80 Slijedom svega što se u 19. stoljeću odvijalo u privredama daleko izvan Pelješca, upravo je ovdašnje pomorstvo požnjelo rezultate prijevozom roba, a naročito svoje mjesto iznašlo u izvozu žita s Crnog mora prema zapadnoj Europi. Iz tamošnjih su pak luka dovoženi izvrsni materijali poput engleskog željeza od kojeg se kovala također tipizirana oprema kuća - npr. dekorativne rešetke prizemnih prozora na cvjetnim prikućima, ili dvorišta - npr. providna ulazna vrata i izdržljive odrine korti, te je, također, opet i briga oko kuće i vrta bila ujednačena.

81 Dobar je broj njih došao zbog zaposlenja na brodogradilištu, ali ono nije dugo radilo - osnovano 1875., ugasilo se s nadolaženjem parobrodarstva kad i Pelješko pomorsko društvo a i nekoliko privatnih jedrenjačkih poduzetnika, jer svi okorjeli pomorci nisu uviđali ni htjeli priznati prednosti novina u općem preobražaju civiliziranoga svijeta. U tome je smislu izostalo i čitko formiranje urbanoga središta, što još uvijek umanjuje poimanje jasnog urbaniteta Orebića. 
82 Pomorske su škole završavali u Italiji i Francuskoj ili Carigradu, zatim u Trstu i Dubrovniku, što ih je već kao mlade približilo mentalitetima zapadnjačkog liberalizma i donekle oslabilo privrženost katoličanstvu, no ne i nacionalnoj kulturi što se odrazilo u pripadnosti većine koljenovića politici narodnog preporoda.

83 Literarno su ih sa zanosom opisali mnogi moderni književnici, lirski pravovaljano očitao Kruno Quien u svojoj pjesmi Biće Orebića: ... Orebić je tamo / gdje se skladno sriču / kuća i vrt / kuća i vrt.

84 Ništa se u tome pogledu nije promijenilo ni s prijelazom na parobrodarstvo kad su romantične uljene slike drvenih jedrenjaka u kućama zamijenili istovrsni portreti i fotografije željeznih brodova na parni pogon. Slike jedrenjaka okupljene su u: NADA FISKOVIĆ, Slikarsko djelo $B$. Ivankovića, Zagreb, 2006. Do danas pak zvanje pomoraca izabire znatan broj Orebićana nalazeći u njemu izvore boljeg ugleda i imetka.

$85 \mathrm{U}$ tome smislu vrijedi upozoriti da u više aspekata nadilaze i jednu i drugu vrstu čak i onih zdanja koje npr. za svoje ladanje bijahu priskrbili patriciji i najjačih gradova osim Dubrovnika. Stanja se naročito očituju u baštini dalmatinskih otoka koji imaju Pelješcu suglasne prirodne i prirodne uvjete, ali su sva htijenja i iskustva u oblikovanju ladanjske arhitekture puno siromašnija od ostvarenja na tlu Dubrovačke Republike. 86 Načelna je usporedba $u$ fenomenu zasigurno malih antičko-rimskih villa rustica, nekoć posijanih i na obali zapadnog Pelješca u očekivano sukladnim ulogama na planu prostorne organizacije, ali još posve neistraženih.

87 Usporediti CVITO FISKOVIĆ, Kulturni značaj povijesnih ladanjskih vrtova u Dalmaciji, Vrtna umjetnost Jugoslavije - povijesno nasljeđe, zbornik istoimenog simpozija, (ur.) Vinko Jurčić, Zagreb-Dubrovnik, 1985.

88 Držimo na umu da je zemlja u prošlosti bila skupa, no radna snaga jeftina, da se kuće pomoraca nisu lako otuđivale osim kad su se pojedine obiteljske loze gasile s njihovim itekako čestim stradanjem na morima.

89 Primjerice ZDRAVKO ŽIVKOVIĆ, Hrvatsko narodno graditeljstvo, II., Ministarstvo kulture i prosvjete, Zavod za zaštitu spomenika kulture, Zagreb, 1992., sintezno ALEKSANDRA MURAJ, Obrisi svakidašnjeg života, JASNA ČAPO ŽMEGAČ et al., Etnografija: svagdan i blagdan hrvatskoga puka, Matica hrvatska, Zagreb, 1998., s raščlambom drugačijih civilizacijskih modela.
$90 \mathrm{~S}$ obzirom na to da su se klesani elementi - kako rekosmo - slijedom običaja i narudžbi Dubrovčana dovozili gotovi iz korčulanskih kamenoloma, gdje se nabavljala i sveukupna oprema dvorišta, te su stupovi odrina - kao tema zasigurno prihvaćeni iz dubrovačkih renesansnih perivoja ali u osnovi antičkog podrijetla - zauzvrat predani korčulanskima, postavši tamo brojniji nego diljem ostale Dalmacije.

91 Iako im je sama kamena građa zadavala neka temeljna pravila izvedbi, važno je uočiti da ne nalikuju inima iz naselja mletačke Dalmacije, nego prate glavninu iz dubrovačke regije, a naglašavaju lokalna obilježja. $\mathrm{Na}$ taj odnos nisu utjecala ni politička opredjeljenja Orebićana, koji su se potkraj razdoblja gradnje većine kuća, baš kao i Dubrovčani, bili podijelili na narodnjake i talijanaše, ali ni time većina nije razlomila svoje nacionalne osjećaje.

92 Općenito ovdje unatoč blizini Korčule zanati nikad nisu uhvatili snažnih korijena, poljoprivreda ne zadovoljava ni lokalne potrebe, ali su pomorska zvanja trajno vrlo jaka.

$93 \mathrm{U}$ istome času kad i Cavtat koji s jačim građanstvom trajno ima razvijenija urbana lica i naličja. Orebići pak ni s četiri-pet puta odonda brojnijim pučanstvom još nemaju službenu kategoriju grada.

94 Urbanizacija Orebića jest odlučno ali bez zreloga plana pospješena tek kad je s administrativno mu pripadajućim okolnim naseljima početkom 21. stoljeća dostigao broj od oko 2000 stanovnika i postao sjedište područne općine s njegovim imenom. Nažalost, već je u drugoj polovini prethodnog stoljeća omasovljena izgradnja kuća, s povijesnoj kulturi ozračja pretežno neprimjerenom kvalitetom arhitektonskog oblikovanja, izazvala mijene vizualnog identiteta, premda se nije iskorijenilo njegovanje vrta kao njihova oduška i ukrasa, pa i kućanskog ponosa.

95 Priklanjam se kategorizaciji iz knjige LJUBO KARAMAN, Problemi periferijske umjetnosti - O djelovanju domaće sredine u umjetnosti hrvatskih krajeva, Zagreb, 1962., gdje je nestor naše discipline sročio ocjenu fenomena retardacija ali i relativnih sloboda stvaralaštva do stupnja vlastitih sinteza nesputanih vanjskim autoritetima.

96 Valja naglasiti da je i desetak kuća do Drugoga svjetskog rata uglavnom građenih kapitalom mjesnih brodara održalo dostojanstvo tradicije po kvaliteti projekata, iako se nisu odreda otvorile modernim trendovima hrvatske arhitekture.

Summary

Igor Fisković

Old Houses of Seamen in Orebicí

The text offers a broad insight into the phenomenon of building a new type of residential houses in the small town Orebici on the Pelješac peninsula, where in the course of centuries people had abandoned farming and the men almost unanimously embraced sea trade and navigation. The article begins by giving us an idea of the first nuclei of the settlement which in the 15th/16th century started turning away from the original and still extant semi-fortified houses, following the Medieval formula of planned urban nuclei in Croatian Southern Dalmatia, after the example of the Dubrovnik Commune. Indeed, the Dubrovnik Republic ruled over Pelješac since the 14th century and transferred their idea of city planning to the peninsula and its centre Ston, encircling it with stone ramparts. This helped Dubrovnik to secure the territory bordering with Venice and protect the farmers of Pelješac who had the status of serfs of the Dubrovnik patricians, earning their living on this rather barren soil.

Living at some distance from Dubrovnik, the local population turned towards seafaring and sea trade in the Adriatic and further on, in the Mediterranean, and those who were successful acquired the status of free citizens had sufficient means to invest in new building. This led from the initial collective living style prevailing in the small early settlements to the construction of individual dwellings which had no urban 
concept, but formed a string of villas surrounded by gardens along the sea coast. This was done in imitation of the Renaissance villas of the Dubrovnik nobility in Orebici. There was something ideological in the wish of these new house owners to show their emancipation on their native soil. The construction of houses continued, with builders who succeeded in creating a typical private residential architecture, quite elitist in comparison with the popular architecture along the Croatian littoral. The new owners took great care to improve their gardens, and their homes, but looking back one can see that these houses had retained some semi-rural characteristics. Such as they were, relying on the morphology of a restrained provincial Renaissance appearance and a pale reflection of Baroque fashion, the houses of Orebic reflected the prosperity of the local "seafaring aristocracy".

This community was both internationally oriented and conservative, and rather lacking in style, but practical, preferring the old symbols of their native tradition to modern aesthetics. Therefore this article does not insist on the formal analysis of these thirty or more very similar large residential houses, built by families of sea captains and shipowners. Rather, it prefers to note the social, psychological and economic aspect of this building venture.

All the way up to the mid-nineteenth century, this community defined the spirit of this little town without forming a strict centre, so that even the institutionalization of the administrative and religious life after the extinction of the Dubrovnik Republic led to no structural transformation. Architecturally this housing complex still rests on the dominant distribution of relatively large, separate buildings, with geometrically ordered interiors and large gardens, making Orebici a quite unique specimen of secular architecture on the coastland of Croatia. Demonstrating the essential conditions of its existence and not too dynamic growth, Orebici remains a rather atypical example in Dalmatia of a cluster of houses which are half urban and half rural, and this remains their greatest value. 